\title{
Quid Pro Quo? What Factors Influence IPO Allocations to Investors?
}

\author{
TIM JENKINSON, HOWARD JONES, and FELIX SUNTHEIM*
}

\begin{abstract}
With data from all the leading international investment banks on 220 IPOs raising $\$ 160 \mathrm{bn}$, we test the determinants of IPO allocations. We compare investors' IPO allocations with proxies for their information production during the bookbuilding and the broking (and other) revenues those investors generate for bookrunners. We find evidence consistent with information revelation theories. We also find strong support for the existence of a quid pro quo: broking revenues are a significant driver of investors' IPO allocations and profits. The quid pro quo remains when we control for any unobserved investor characteristics and investor-bank relationships.
\end{abstract}

June 2017

Key words: Initial public offerings, allocations, conflicts of interest JEL classification: G30, G24

\footnotetext{
* Tim Jenkinson (tim.jenkinson@sbs.ox.ac.uk) and Howard Jones ((howard.jones@sbs.ox.ac.uk) are at the Saïd Business School, University of Oxford, Oxford OX1 1HP, UK; Felix Suntheim (felix.suntheim@,fca.org.uk) is at the UK Financial Conduct Authority, 25 North Colonnade, Canary Wharf, London E14 5HS. The views expressed in this paper are those of the authors and not the Financial Conduct Authority.
} 


\section{Introduction}

Initial public offerings (IPOs) play an important role in the financial system, enabling companies to raise equity finance and providing investors with a tradeable asset. However, doubts remain about how well the IPO market operates for issuing companies. The IPO boom in the U.S. during the dot-com period - in particular 1999-2000 - witnessed several scandals, including laddering, spinning ${ }^{1}$, analysts' conflicts of interest, as well as heavily underpriced shares being allocated in return for excessive trading commissions (Liu and Ritter (2010)). There followed a dearth of IPOs for much of the 2000s, even before the 2008 financial crisis (Ritter (2013)). Regulators also responded by outlawing specific practices and requiring investment banks to implement policies to address conflicts of interest. In the U.S., concerns that financial markets were not effectively serving the needs of growing companies motivated the passing of the JOBS Act. ${ }^{2}$

In the U.K., the Financial Conduct Authority (FCA) began a review of wholesale financial markets in $2014 .^{3}$ This led to the launch of a market study into investment and corporate banking in May 2015. The research in this paper was conducted alongside the market study, and benefits from the sort of data that has not previously been available to researchers. All banks with operations in the U.K., which include all the leading U.S. and European investment banks, are subject to regulation by the FCA. The FCA used its powers to gather detailed information on bids, allocations, meetings before and during the bookbuilding, fees, the economic relationship

\footnotetext{
${ }^{1}$ Laddering is the practice of allocating shares on the understanding that investors will buy additional shares in the immediate aftermarket. Spinning refers to the practice of allocating shares to corporate executives in order to influence their decisions in future corporate investment banking transactions.

2 The Jumpstart Our Business Startups Act was passed into law in 2012 and requires the SEC to write rules that facilitate cost-effective access to capital for companies of all sizes while promoting investor protection.

${ }^{3}$ This Wholesale Sector Competition Review was launched in July 2014 (FCA, 2014) with a discussion document that invited responses from market participants on a range of issues. In February 2015 the FCA issued a feedback statement (FCA, 2015a) on the views that had been expressed, and announced that they would launch two market studies. The first would focus on Investment and Corporate Banking, and the second on Asset Management. The Terms of reference for the former, to which this paper is related, were published in May 2015 (FCA, $2015 \mathrm{~b}$ ) with questionnaires and data requests being sent out to relevant parties in June 2015. The interim report of the market study was published in April 2016 (FCA, 2016).
} 
between investment banks and their buy-side clients, and various other data for all IPOs conducted from the U.K. between January 2010 and May 2015. ${ }^{4}$ Since many banks have their European headquarters in London, the sample covers companies being floated on most European exchanges. The companies are from across Europe, as well as some from Africa and the MiddleEast. Our sample comprises 220 IPOs raising $\$ 160$ billion, representing around three-quarters of the Europe, Middle-East, and Africa (EMEA) market, by value, over this period. ${ }^{5}$

The main question we address is how IPO allocations are determined. The underpricing of IPOs is well documented and represents 'money left on the table' for the original owners of the company. ${ }^{6}$ That money is picked up by those who are allocated shares at the IPO that immediately trade higher than the offer price. We test the extent to which IPO allocations and the money left on the table at IPOs are determined by information revelation or by the revenues generated for the bookrunner by buy-side investor clients as part of a quid pro quo. The extent of these revenues - which has not previously been documented - is considerable, averaging \$37 billion per year across the banks in our sample. ${ }^{7}$ By comparison, we estimate that IPOs generated investment banking fees averaging $\$ 437$ million per year.

The information revelation and quid pro quo hypotheses are clearly not mutually exclusive: investment banks may favor investors who submit informative bids as well as those from whom they derive the highest revenues. One challenge researchers encounter is that not all of the interaction between investors and investment banks is observable. We can observe, for example, bidding behavior and participation in road-show meetings, but we cannot observe more informal interaction. Furthermore, it is possible that investment banks have deeper relationships

\footnotetext{
${ }^{4}$ Conducted from the U.K. means all activities undertaken from or in the U.K., regardless of the location of the client or the legal entity into which the activity is booked for accounting reasons.

${ }^{5}$ IPOs on the U.K. exchange constitute around one-quarter of our sample, by value.

${ }^{6}$ Jenkinson and Ljungqvist (2001) survey the academic evidence on underpricing, and Jay Ritter produces a wealth of data for the US and other countries on his website https://site.warrington.ufl.edu/ritter/ipo-data/.

7 These revenues vary by investor depending on the services they buy from the bank, such as broking services (across equities, fixed income, derivatives etc.), research (often bundled as part of trading commission), currency hedging, and, in the case of hedge funds, a variety of 'prime brokerage' services.
} 
with their best (i.e. higher revenue) customers, and that these result in more information revelation. We are able to confront these challenges with our unique dataset by controlling for the impact of investor-specific characteristics that are fixed across IPOs run by different banks, and for any specific (non-revenue related) investor-bank relationships.

Our main results are as follows. First, we find evidence that the way investors bid influences allocations. We analyze three characteristics of bids: whether they are price-limited, whether they are submitted early, and whether the bids are revised during the bookbuilding. Previous research has interpreted these bid features as providing information and has found that bookrunners reward such bids with better allocations. ${ }^{8}$ Regarding price-sensitive bids - as opposed to 'strike' bids that demand a quantity of shares without specifying a price limit - we find that such bids receive a slightly higher allocation across the whole sample of IPOs. However, when we run our econometric models separately for each of the leading investment banks, we find considerable variation. For some banks, allocations are similar regardless of the type of bid that investors submit. We find little evidence that either bidding early, or revising bids during the bookbuilding, has any significant impact on allocations.

Second, we analyze whether bidder characteristics or actions during the bookbuilding process affect allocations. We find that investors who participate in meetings before or during bookbuilding receive more generous allocations. Although it is impossible to know how much information flows from investors to the bookrunners during such meetings, participation may demonstrate a more active engagement with the IPO and the issuer, and the evidence suggests that bookrunners reward such investors. Being a frequent bidder also has a small, positive impact on allocations. Regarding bidder characteristics, we find that allocations to hedge funds are scaled back significantly more than those to long-only investors, although they still receive around one-fifth of all shares across our sample of IPOs.

Third, we find that investor revenues have a significant impact on IPO allocations. We measure the economic relationship between investors and banks by constructing, for each IPO, a

\footnotetext{
${ }^{8}$ Following the existing literature, we focus on allocations relative to bids, or 'normalized rationing' - the ratio of the proportionate allocation relative to the proportionate quantity bid for (at the issue price); see Cornelli and Goldreich (2001).
} 
quartile ranking of investors based on how much revenue they generate for the bookrunner (from all activities, and not just from the trading of any particular IPO). For the overall sample, we find that allocation rates increase steadily across the investor-revenue quartiles. Top quartile investors, by revenue generation, receive allocations relative to the amount they bid that are around $60 \%$ higher than those received by investors who generate no revenue for the bookrunner. We find significant, but smaller, revenue effects for the second and third quartiles of investors. When we run separate regressions for each of the top banks we find interesting heterogeneity. The pattern is broadly the same across most of the individual banks, although for two banks investor revenues appear to have at most a weak impact on IPO allocations. Therefore, the majority of the largest banks allocate shares more generously to their investor clients that generate the most revenues.

Fourth, we assess whether the association between revenues and allocations remains when we control for investor and investor-bank fixed effects. If investor information production is not fully captured by our observable measures, it could be that high revenue clients - who will tend to be larger investors - are more sophisticated, generate more information, and have closer (but unobservable) relationships with investment banks. If this were so, the more generous allocations to high-revenue investors could be a reward for information production rather than a quid pro quo. When fixed effects are included, we find that the marginal impact of changes in revenue ranking between IPOs is still significant, increasing in revenues, and larger in hot IPOs. ${ }^{9}$ This is even the case when we include investor-bank fixed effects. An investor active in two IPOs run by the same bank may be in the top revenue quartile in the first IPO (alongside many low revenue investors) but a lower quartile in the second IPO (alongside many higher revenue investors). Even under this test, the top two revenue quartile variables are still significant, positive, and increasing in revenues, implying that an investor who participates in different IPOs run by the same bank will receive a higher allocation in the IPO in which it is more important, relative to other investors, to the bank in revenue terms. These results suggest that the relationship between investor revenues and IPO allocations is not simply an artifact of some unobserved investor or investor-bank effect that involves information production.

\footnotetext{
${ }^{9}$ We designate IPOs as hot when the time taken for the book to be covered (i.e. demand equals supply at the bottom on the price range) is quicker than the median.
} 
Finally, we test whether high revenue investors also earn higher expected profits. After all, if such investors were more generously allocated only in IPOs with low expected returns, their bids could end up being less profitable than those of other investors. The findings of this analysis are that the top three revenue dummies are positive, significant, and economically important determinants of expected profitability.

Our research contributes to the existing literature in several ways. No previous authors have obtained IPO allocation books, which are critical for testing the alternative theories, from all investment banks operating in an important market. Cornelli and Goldreich (2001) obtained books for 39 IPOs run by one European investment bank, while Jenkinson and Jones (2004) obtained allocation books for 27 IPOs run by another. The former found that price-sensitive bids and bids revised during the bookbuilding were favored, while the latter found no such evidence. Our results show that there is noticeable variation across banks in the extent to which bidding behavior influences allocation, which can explain the earlier conflicting results obtained for individual banks. Furthermore, no previous authors have obtained allocation books for any of the major U.S.-based investment banks. And, in the light of the various scandals, fines, and regulatory interventions, we are able to explore whether behavior has changed since the earlier studies, whose samples were pre-2001.

Previous studies have analyzed quid pro quos. Reuter (2006) obtained information on broking commissions paid by mutual funds to a particular underwriter and finds that these are correlated with their holdings of stocks that have recently conducted an IPO managed by that underwriter. Goldstein, Irvine, and Puckett (2011) find evidence that investors increase round-trip stock trades and pay unusually high trading commissions to bookrunners around the time of an IPO. However, neither of these studies has access to banks' allocation books and they are therefore unable to explore a direct link between the two sides of a possible quid pro quo. ${ }^{10}$ Our study is the first to obtain the total revenues generated by each investor, each year, for each bookrunner. By combining this revenue data with detailed information from the bookbuilding, we

\footnotetext{
${ }^{10}$ This constraint is also faced by Ritter and Zhang (2007), who investigate whether IPO underwriters favor affiliated mutual funds, and Nimalendran, Ritter, and Zhang (2007), who investigate whether there is a positive relationship between trading volume, and hence trading commission payments, in liquid stocks and subsequent money left on the table in IPOs.
} 
are able, for the first time, to test for the relative importance of information revelation and quid pro quos in determining IPO allocations.

A further contribution of the paper is to document, and test the impact of, developments in the primary equity market, as far as it operates in Europe. An important innovation has been issuers' use of corporate finance advisors (sometimes called 'independent IPO advisors'), which been a response to the potential for conflicts of interest faced by investment banks. We find that the presence of a corporate finance advisor leads investors in an IPO to submit more informative bids, but does not significantly affect the allocation-revenue relationship. We also gather information on IPO fees. We find that most IPOs in our sample have a fixed fee element, as well as a discretionary component which depends on how satisfied the issuer is with the performance of the bank in executing the IPO. These two features of European IPOs - corporate finance advisors and discretionary fees - appear to be less widespread in the U.S. ${ }^{11}$

The link which we establish between IPO allocations and revenues points strongly to a quid pro quo between the two. This may mean that bookrunners are making IPO allocations against the interests of the issuer, for example to high-revenue clients who flip their shares when trading begins, placing downward pressure on the stock. However, alternative explanations exist. In competitive IPO markets underwriters might pass on to the issuer at least some of the benefits of the incremental broking revenues they receive through lower fees or narrower underpricing. In such a setup, quid pro quos could be an efficient, albeit opaque, way for underwriters to price discriminate between investors who are desirable from the issuers' perspective, and other investors. ${ }^{12}$ The welfare implications of quid pro quos are therefore ambiguous.

The remainder of the paper is organized as follows. In the next section we describe the data and discuss recent developments in the way IPOs are conducted. In the third section we analyze the determinants of allocation. We run initial models including only the informationrevelation proxies, and then test the impact of including investor revenues. In section four we

\footnotetext{
${ }^{11}$ The IPO fees paid in our sample of IPOs are similar in size to the findings of Abrahamson et al. (2011), averaging around $2.8 \%$ of proceeds.

${ }^{12}$ See for example Benveniste and Wilhelm (1990) for a discussion of how uniform-price restrictions increase the cost of soliciting information from investors.
} 
analyze whether the relationship we find between investor revenues and IPO allocations is evidence of a quid pro quo relationship, and discuss the welfare implications for issuers. Section five concludes.

\section{Institutional Setting and Data}

IPOs outside the U.S. have historically been conducted using a variety of techniques (Jenkinson and Ljungqvist (2001)), but in recent years IPOs in most major markets have been carried out under the U.S. bookbuilding approach (Ljungqvist, Jenkinson, and Wilhelm (2003)). This is true for the - predominantly European - IPOs in this study. At the same time, the European IPO market has innovated beyond U.S. practice, mainly in the structuring of fees and the use of corporate finance advisors, and we explore the effects of these developments on IPO outcomes. In this section we describe the institutional setting, provide a description and breakdown of the data, and explain how we construct the key variables for the econometric analysis.

\section{A. $\quad$ Our Sample of IPOs}

IPOs are typically conducted by syndicates of investment banks with one or more banks acting as bookrunner, and other banks playing a more junior role (see Corwin and Schultz (2005) on the structure of syndicates and Hu and Ritter (2007) on the use of multiple bookrunners). As a generalization, the bookrunners perform the following roles in IPOs: they advise the issuer on an indicative price range within which to offer the shares; they receive orders directly from all investors, who state the size of their demand together with any price limits, as well as disclosing their identity; they keep a running record of demand (i.e. they 'build a book'); and they recommend to the issuer the price which should be set for the IPO and how to allocate the shares among investors. Other syndicate banks are generally not involved in these activities. ${ }^{13}$

\footnotetext{
${ }^{13}$ Industry participants make a distinction between bookrunners who are 'active bookrunners' (who in many IPOs are also given the title 'global coordinators') and bookrunners who are not. Only 'active bookrunners' perform the order-taking, record-keeping, and allocation functions described here. In this paper only 'active books' are included in our definition of bookrunners, because our focus is on those parties that make pricing and allocation decisions. Even under this narrow definition of bookrunner, a number of the IPOs in our sample have multiple bookrunners. Information on bank roles in an IPO was given to the FCA as part of the information request.
} 
All banks operating in the U.K., which includes all the leading U.S. and European investment banks, were required to provide information on IPOs managed from their U.K. offices between January 2010 and May 2015, regardless of the location of issuer, listing authority, or target investors. While the regulatory review of wholesale markets was launched in June 2014, after which there was an initial consultation phase, the announcement that the IPO process would be a focus of attention was not announced until May 2015. There had been no prior speculation in the press that IPOs were to be investigated. Therefore, we do not believe that investment banks anticipated the regulatory attention, which could have resulted in changes in allocation practice. Furthermore, as we explain later, in our regression analysis we include annual investor revenues, and the latest year for which these are available is 2014. Consequently, we exclude any 2015 IPOs from our regression analysis.

In total, 32 banks provided 801 books (of orders and allocations) on 410 IPOs over the sample period. The difference between the number of books and the number of IPOs reflects the fact that in many cases more than one bank provided data on the same IPO. We exclude 125 fixed-price IPOs and 30 IPOs conducted using other non-bookbuilding methods or where only partial information was provided. We then ignore 190 books submitted by banks that were not bookrunners. These filters reduce the sample to 431 books on 255 IPOs. We then apply two further filters. First, we exclude 25 books with information on the final state of demand but without bid histories, which we require as they contain variables which are key to our analysis. Second, we remove books which include allocations relating to less than $75 \%$ of the total shares which (according to the publicly available Dealogic database) were sold in the IPO, on the grounds that these books were incomplete. ${ }^{14}$ The final sample comprises 372 books from 19 banks on 220 IPOs.

Table 1 provides information on the distribution of our sample. As is well known, IPOs tend to come in waves, and this is a feature of our sample period (see panel A). Our sample includes only 17 transactions from 2012, whereas in 2014 there were 77 . The total capital raised by the firms in our sample is nearly $\$ 160 \mathrm{bn}$, with the median IPO raising $\$ 477 \mathrm{~m}$. To give a sense of what proportion of the IPO market our sample covers, we use data from Dealogic to calculate

\footnotetext{
${ }^{14}$ We also dropped one unusual IPO for which only three distinct investors were recorded.
} 
the total IPO proceeds raised by issuers on EMEA exchanges - which is a somewhat broader classification than our sample of transactions managed by banks operating in the U.K., but is the closest estimate of the overall market. For the corresponding period the total amount raised was $\$ 211 \mathrm{bn}$, so our sample represents around three-quarters of EMEA IPOs by value. ${ }^{15}$

Table 1 also contains details of the primary exchange on which the issuers listed (see panel B), with London-listed IPOs comprising around one-third of the total number of IPOs in the sample. Panel C shows the main country of origin of the issuing companies. Again, the U.K. has the highest number of IPOs, but under one-quarter of the IPOs are for U.K. firms - which reflects the fact that many non-U.K. companies choose to list in London. 20 companies in our sample listed on multiple exchanges.

\section{B. Fees, Syndicate Structure, and the Role of Corporate Finance Advisors}

The explicit remuneration received by banks for participating in IPOs is the fee paid by the issuer, expressed as a percentage of IPO proceeds. ${ }^{16}$ The main variation in market practice in our sample is whether part of this remuneration takes the form of a 'discretionary fee'. In IPOs without a discretionary fee, the apportionment of fees is in line with U.S. practice. That is, the total fee is largely pre-agreed among the bookrunners and the other syndicate banks, typically pro-rata to their underwriting of the IPO. In IPOs with a discretionary fee, part of the total fee is pre-agreed (again pro-rata to underwriting), but the discretionary part is paid to syndicate banks at the issuer's discretion. The issuer may even choose not to pay out this discretionary fee at all.

The introduction of discretionary fees is one of two major innovations in European IPOs over the last ten years. The other is a growing tendency by issuers to appoint a corporate finance advisor for their IPO. Corporate finance advisors - such as Lazard, Rothschild, and STJ Advisors - are used on IPOs for a number of reasons, including as a response to the potential conflicts of interest that investment banks face when balancing the interests of their buy-side clients and the

\footnotetext{
${ }^{15}$ The proportion by value varies by year from a low of $65 \%$ in 2012 to $83 \%$ in 2015 . Given that we focus on bookbuilt IPOs, which tend to be medium to large transactions, the proportion of IPOs by number of transactions in our sample is much lower: our 220 IPOs compare to 707 total IPOs in the Dealogic sample.

${ }^{16}$ We use the term 'issuer' indifferently both for firms issuing new shares and for pre-IPO owners selling existing shares.
} 
issuing company. The services that they provide before the launch of the IPO include helping to select the bookrunner and other syndicate banks, and recommending investors and markets to target in the IPO. During the offering the corporate finance advisor guides the issuer in setting the indicative price range and the final price, and in choosing the investors to receive an allocation. After the IPO, in cases where there is a discretionary fee, they may recommend whether and how this fee should be paid out among the syndicate banks according to their respective contributions. Therefore, corporate finance advisors provide issuing firms with support at critical decision points - in particular, choosing the bookrunner, pricing, and allocation.

Information on syndicate structure, IPO fees, and the prevalence of corporate finance advisors, is provided in Table 2. On average, a syndicate includes around five banks, but the range in our sample is large (see panel A): some, generally smaller, IPOs are handled by a single bank whereas two IPOs involve 19 banks. The mean number of active bookrunners is 1.69. Recall that, under our definition, bookrunners are the banks that actually run the process and have the most complete information (i.e. are 'active bookrunners'); the number of banks designated as bookrunners on the IPO prospectus is around twice as high (the mean is 3.38 per IPO). We identify corporate finance advisors as having a role in the IPO for around one-third of the sample. These 'advised IPOs' tend to be larger in terms of transaction value. ${ }^{17}$

We obtain fee information for 188 of the 220 IPOs (fees for European IPOs are not always reported). As we show in Panel B of Table 2, the mean (median) fee is $2.77 \%$ (2.50\%) for our sample. This is similar to the fees found by Abrahamson et al. (2011) for their sample of European IPOs conducted from 2001-2007. They found average fees of 3.34\% for IPOs raising $\$ 100-500 \mathrm{~m}$ and of $2.39 \%$ for larger IPOs (the median size of IPOs in our sample is $\$ 477 \mathrm{~m}$ ). All IPOs in our sample have a fixed fee and $71 \%$ of IPOs also a discretionary fee. The mean (median) discretionary fee that was paid for our sample is $0.45 \%(0.34 \%)$, which represents $16.3 \%(13.6 \%)$ of the total fees paid. Larger IPOs are more likely to have a discretionary fee: among the top quartile of IPOs by value $87 \%$ had discretionary fees. Therefore, for a typical (top

\footnotetext{
${ }^{17}$ We run a probit regression for the incidence of corporate finance advisors, with issuer sector - industrial, bank, other financial, or utility (source Dealogic) - IPO size, region, and number of bookrunners as explanatory variables. Only IPO size is statistically significant.
} 
quartile) $\$ 700 \mathrm{~m}$ IPO, the discretionary fee payment could be around $\$ 3.15 \mathrm{~m}$ (using the mean discretionary fee of $0.45 \%$ ). Information on the maximum potential discretionary fee is not available, but the qualitative evidence received from banks suggests that the discretionary fee is paid in full in about $50 \%$ of cases. One reason for the higher incidence of discretionary fees among larger IPOs could be that they are more likely to have a corporate finance advisor. It is also noticeable that the proportion of the total fee that is discretionary is higher when there is a corporate finance advisor: the mean (median) proportion is $29.5 \%$ (22.5\%) for advised IPOs, and $12.4 \%$ (6.4\%) for IPOs without a corporate finance advisor.

\section{Investors and Bidding Behavior}

Investor demand in our sample of book-built IPOs is overwhelmingly institutional. Moreover, demand from retail investor clients tends to be institutionalized in the sense that it is consolidated by banks which place block orders on behalf of private clients. An important strength of our dataset is that it is derived from a large number of banks. However, this also creates challenges when analyzing investors. In particular, investor names are not consistently recorded either across banks or, in some cases, within a given bank (both across IPOs and for different parts of the information provided, such as allocation books, information on meetings, and revenue data). In some cases, the differences are trivial, involving special characters (in particular accents), abbreviations, and misspellings. However, investor names can also have legal or descriptive terms attached ('fund', 'plc' etc.) or refer to a specific geographical location ('Geneva', 'U.K.', etc.). In the latter case the question of whether to match investors with and without the geographical reference is more debatable. In some cases the investor will be identical - 'XYZ fund' may be the same as 'XYZ fund, Geneva'. However, there will be other cases where XYZ fund submits bids from two separate geographical offices. In this case, the decision to match the names - and so treat them as a single investor - depends on whether the bids are submitted by the same decision maker and whether they are treated as a single investor by the investment bank. In general, when we match books, revenues, meetings, and trade data, we do so in two stages: first we match investors using a 'narrow' match that only corrects spelling mistakes and ignores special characters and abbreviations; we then take the unmatched investors 
and conduct a 'wide' match that treats investors from an investment group as a single unique investor. $^{18}$

Across the 220 IPOs in our sample we identify about 9,000 distinct investors using the narrow match, and about 16,000 using the wide match, who submitted around 41,000 bids. In Table 3 we present summary information on these bids. Bidding behavior can be described under the following headings: price sensitivity, timing, and revisions. Price sensitivity is reflected in limit bids, which include a maximum price per share that the investor will pay. A subset of these are step bids, by which investors break their demand down into a schedule of sub-orders, each with its own price limit. Bids that do not include a price limit are strike bids, meaning that investors are prepared to pay up to the top of the bookbuilding range for the shares. ${ }^{19}$ The issue of price sensitivity is important as those bids that include a price limit, as well as a maximum quantity, can be considered more informative to issuers, and, to the extent that allocations are used to reward investors for the revelation of information (Benveniste and Spindt (1989)), may result in preferential allocations. Table 3 shows that, in the average IPO, $46.6 \%$ of bids are price sensitive bids (limit or step). The table also shows this breakdown separately for 'hot' and 'cold' IPOs, where hot (cold) IPOs are the half of the sample in which the shares offered were quickest (slowest) to be fully subscribed by investors at the bottom of the bookbuilding range. ${ }^{20}$ The

\footnotetext{
${ }^{18}$ In the Internet Appendix we provide more information on the matching procedure and check our main results for robustness with respect to the way we match investors.

${ }^{19}$ Money bids (also shown in Table 3) are those in which bidders express their demand as a money amount rather than as a number of shares. Bidders placing money bids can be certain about the maximum size of their investment, whereas those bidding for a number of shares are exposed to uncertainty about the size of their eventual investment until allocation. Money bids can be viewed as indirectly price sensitive in that the number of shares bid for declines the higher the IPO price is set.

${ }^{20}$ We use this ex-ante measure of 'hotness' because it is communicated to investors during the IPO. An alternative measure of 'hotness' is the level of oversubscription (i.e. the ratio of demand to supply). However, this is an ex-post measure that is not known for certain until after the end of the bookbuilding (order-taking) period. We present results using this latter measure in the Internet Appendix.
} 
incidence of price-sensitive bids varies sharply according to the hotness of the IPO, with an average of $30.0 \%$ of bids being price-sensitive in hotter IPOs versus $55.6 \%$ in colder IPOs. ${ }^{21}$

Institutional investors are commonly divided into two broad classes: long-only investors and hedge funds. Long-only investors, typically pension funds, insurance companies, sovereign wealth funds, and endowments, are expected to have a long-term investment horizon (although they are not precluded from taking a short-term view). Hedge funds may apply a number of investment approaches, but some will have a very short-term investment outlook. This is acknowledged by the IPO bookrunners in our sample who, in their meetings with the FCA, stated that the main perceived benefit of including hedge funds as investors in IPOs is that they provide aftermarket liquidity. To gain a sense of the relative importance of long-only investors and hedge funds as IPO investors, we used investor classifications of long-only, hedge fund, or mixed/undefined. These classifications are consistent with those provided by a leading corporate finance advisor. ${ }^{22}$ For those that could be clearly defined, roughly equal numbers of investors were classified as hedge funds and long-only. We investigate whether allocations are influenced by the type of investor in the next section.

Finally, we have information on the meetings held between the issuing firm and potential investors before and during the IPO. Private meetings held before the launch of the IPO are referred to by industry participants as 'pilot fishing' ${ }^{23}$ Meetings after the launch of the IPO may

\footnotetext{
${ }^{21}$ This inverse relationship between price-sensitivity and hotness is in line with the findings of two papers which have studied the levels of price-sensitivity in European IPO books: Cornelli and Goldreich (2001), which found more price-sensitivity in a colder sample, and Jenkinson and Jones (2004), which found less price-sensitivity in a hotter sample.

${ }^{22}$ This has the advantage of allowing us to classify different types of investors in a way that is consistent with market participants' classifications. The data allows us to classify about $50 \%$ of investors as hedge fund, long-only fund or others. There are cases where one investor is matched to two different investor types. In these cases we classify the investors as 'mixed' and do not include them in the hedge fund or long-only sample.

${ }^{23}$ This terminology is used in Europe, but meetings that occur before the IPO is launched also take place in the U.S., where they are referred to as 'testing the waters' meetings. In general, testing the waters meetings occur early in the IPO process and although they do not involve a direct discussion of valuation, the underwriters will obtain an indication of the level of interest in the offer. Pilot fishing meetings in Europe can take place at any time before the launch of the IPO and, if they occur shortly before launch, they may include discussion of valuation.
} 
be one-on-one or they may be part of (non-public) group presentations by the issuer's management. Participation in meetings may be related to information production/gathering by investors, who may then contribute their views to the bookrunners either directly at the meetings, or via their subsequent bids. However, the extent to which useful information is communicated to the issuer or their investment bank as a result of such meetings is unknown. Table 3 shows that, in the average (median) IPO 20.4\% (18.9\%) of investors participated in at least one meeting; $6.4 \%$ (4.2\%) of investors attended the pilot fishing. Attendance of meetings or pilot fishing does not vary substantially between hot and cold IPOs.

\section{Investor Broking Business with Bookrunners}

A number of studies have argued that bookrunners make preferential allocations to investors with whom they do broking business (Reuter (2006), Jenkinson and Jones (2009), Goldstein et al. (2011)). However, no previous paper has had direct access to information on IPO allocation books and total revenues generated by investors, let alone for all IPOs in a major market over a 5-year period. If there is a link between IPO allocations and broking business, this could mean that bookrunners profit from IPOs, not only through IPO fees, but through the extra broking commissions generated from investors favored in IPO allocations. As part of its information request the FCA asked both banks and buy-side investors whether they believed that IPO allocations were motivated by the wider business relationship between the two sides. The responses indicate a sharp difference of opinions between these two groups of respondents. ${ }^{24} \mathrm{On}$ the whole, banks considered that their business relationship with investors had little or no impact on IPO allocations, and noted that this practice was in line with their own stated allocation policies, which form part of the conflicts of interest policy that the FCA requires banks to produce. Banks' internal allocation policies vary in their wording but those of the most active bookrunners were largely similar in content and explicitly prohibit any quid pro quo arrangement between IPO allocations and compensating benefits. Here is an extract from one such policy: 'The amount of trading commission or other income received or expected to be received by the Firm from a particular investor client should not be a relevant factor in the decision to allocate

\footnotetext{
${ }^{24}$ See Figure IA. 1 in the Internet Appendix.
} 
securities to that client. [...] Prohibited allocation practices: [...] Any other type of "quid pro quo" arrangement under which an allocation is made conditional on or linked with a compensating benefit such as the investors" participation in a "cold" deal or payment of excessive commissions on trading in the aftermarket or in other securities.'

Buy-side investors, on the other hand, were more inclined to see a positive link between their business relationship with the bookrunner and IPO allocations. The difference between the responses of banks and investors on this point is striking because the responses of banks and investors to other questions in the survey are broadly similar.

Each investment bank was asked to provide the annual revenues they derived from each of their investor clients for each year from 2010-14 inclusive. ${ }^{25}$ In Table 4 we present the total revenue, by year, across all banks and for the top five banks separately. Revenues from investors average \$37.4 billion per year over the sample period. Information is less complete for 2010, for which some banks were not able to provide data, but the overall revenues for the remaining years are remarkably stable, varying between $\$ 37.7$ billion and $\$ 41.0$ billion. Among the top five banks by revenues we see large differences in terms of the number of investors and the size of the revenues they generate. These revenues from investors dwarf the fees investment banks receive from issuers for conducting IPOs. Over the same years, investment banking fees from IPOs averaged $\$ 437 \mathrm{~m}$ per year, or just over $1 \%$ of the revenues generated (outside IPOs) by investors.

\section{E. IPO Outcomes}

The outcome of an IPO can be expressed in terms of demand, allocation, and pricing. As shown in Table 5 (panel A), the total demand, at the offer price, divided by the total allocation (the subscription rate) averages 4.5 in our total sample of IPOs. The sample is skewed, with some IPOs being very heavily oversubscribed (28 times in the case of one IPO). The median level of subscription is 2.6. Table 5 (panel B) also shows the average and median total allocation for different investor categories and for hot and cold IPOs. The categories of long-only investors and hedge funds each represent on average around a quarter of total demand, but hedge funds receive an appreciably lower percentage of the allocations ( $18 \%$ vs $28 \%$ for long-only investors). In

\footnotetext{
${ }^{25}$ The data request was not limited to revenues from brokerage business but included all services provided to an investor.
} 
Section 3 we explore the 'normalized rationing' (i.e. the percentage of total allocation divided by the percentage of total demand) of these investor categories in a multivariate setting.

Table 5 (panel A) also shows that the IPOs in our sample are priced, on average, at $40 \%$ of the initial price range (taking the whole span of the price range as 100\%). As Figure 1 illustrates, all but nine IPOs in our sample were priced within the indicative pricing range set for the IPO. The final pricing was clustered at three points: the lower and upper bounds and the midpoint. This 'stickiness' of the initial price range in European IPOs has been noted previously by Jenkinson, Morrison and Wilhelm (2003) who show that this outcome could be the result of more information being revealed before the price range is set (for example in the pilot fishing meetings). ${ }^{26}$ Table 5 (panel A) shows that the average initial returns for IPOs in the sample are $4.8 \%$ and $5.4 \%$ for the first day and first week respectively. It is noteworthy that the initial returns on IPOs in EMEA during the sample period were low by historical standards, ${ }^{27}$ and lower than first-day returns for U.S. IPOs during the same period (which averaged $12.6 \%$ for 20102014). ${ }^{28}$ As Table 5 shows, IPOs in which there was a corporate finance advisor show slightly lower mean and median first-week returns than those of other IPOs. ${ }^{29}$

\footnotetext{
${ }^{26}$ In a sample of European IPOs analyzed by Jenkinson, Morrison and Wilhelm (2003), 44\% of IPOs were priced at the upper bound of the range, and only $7 \%$ at the lower bound, with a similarly low fraction of around $10 \%$ priced outside their initial range. In contrast, they report almost $50 \%$ of a comparable sample of US IPOs were priced outside the initial price range. The authors provide a possible theoretical justification for such practice within an information revelation model, but they do not take account of quid pro quo incentives.

${ }^{27}$ According to Chambers and Dimson (2009) average underpricing of IPOs on the LSE for 2000-2007 was 19.86\%, median underpricing was $8.5 \%$.

${ }^{28}$ Average underpricing in the US was $12.6 \%$ in 2010-2014 (Jay Ritter, https://site.warrington.ufl.edu/ritter/ipo-data/, February 2016). On developments in U.S. IPOs and comparisons with non-U.S. IPOs, see Abrahamson et al. (2011); Ritter (2011); Caglio, Hanley, and Marietta-Westberg (2012); and Doidge, Karolyi and Stulz (2013)).

${ }^{29}$ First day returns are also slightly lower for those IPOs with a corporate finance advisor, but median returns are marginally higher for this group.
} 


\section{IPO Allocations and Buy-Side Revenues}

As mentioned in the introduction, investment banks face a potential conflict of interest when advising issuers in the IPO allocation process. The banks are engaged, and paid, by the issuer, but underpricing of IPO shares makes them desirable for the buy-side investor clients from whom investment banks earn significant revenues. In this section we test the extent to which allocations are influenced by revenues received from buy-side clients and by proxies for information production (in line with Benveniste and Spindt (1989), where preferential allocations are used to reward investors for revealing information that is valuable to the bookbuilding process.)

To understand if an investor receives a relatively more favorable allocation we calculate the normalized rationing of their bids. This allows our results to be compared to earlier analyses by Cornelli and Goldreich (2001) and Jenkinson and Jones (2004). Normalized rationing is the allocation-to-bid ratio of an individual investor divided by allocation-to-bid ratio of all investors in that IPO. The higher the normalized rationing variable for an investor, the less that investor's demand is scaled back compared with other investors in the IPO. For example, normalized rationing of one means that an investor is scaled back in line with the scaling back in that IPO as a whole, and normalized rationing of 0.5 means that an investor is scaled back twice as much as the scaling back in the IPO as a whole.

Table 5 (panel C) shows normalized rationing for different investor types and IPOs. The average normalized rationing per investor is 0.78 . Investors who have high revenues with banks have on average higher values, i.e. are scaled back less than other investors. We also see that long-only funds are treated more favorably than hedge funds. To the extent that the former are perceived as more likely to be long-term holders than the latter, this would be consistent with previous survey evidence that allocations favor long-term investors.

Disentangling the various attributes of investors is clearly a challenge. It is possible that buy-side investors who pay high broking revenues to syndicate banks have characteristics that are genuinely desirable for the issuer: they may contribute to the price discovery process or be likely to become long-term shareholders. To estimate the impact of the various possible determinants of allocation, as suggested by the alternative theories, we use an econometric analysis.

\section{A. Econometric Approach}

We follow earlier studies and regress normalized rationing on bid and bidder characteristics. In doing so, we shed new light on the bookbuilding process in three main ways. 
First, we test directly whether the revenues generated by IPO investors for bookrunners have an impact on allocations. Second, we have unprecedented detail on bid and bidder activity before and during IPOs, notably on investor meetings, allowing us to compare information revelation and agency effects as explanations for allocations. Third, with IPO data from all the leading bookrunners we can explore the contradictory findings from earlier single-bank studies. We start by estimating the models using the whole sample of IPOs, and then test the extent of variation in allocation practices across the leading banks.

As explained above, normalized rationing is the ratio of percent allocated to percent bid. Our baseline regression is specified for each investor $i$, active in IPO $\mathrm{j}$, with bookrunner $k$ as:

$$
\begin{aligned}
\text { Normalized rationing }_{\mathrm{i}, \mathrm{j}, \mathrm{k}} & =\alpha+\sum_{\mathrm{n}=0}^{\mathrm{N}} \beta_{\mathrm{n}} \text { bid characteristic }_{\mathrm{i}, \mathrm{j}, \mathrm{k}, \mathrm{n}}+ \\
& \sum_{\mathrm{n}=1}^{\mathrm{N}} \gamma_{\mathrm{n}} \text { bidder characteristics }_{\mathrm{i}, \mathrm{j}, \mathrm{k}, \mathrm{n}}+\sum_{\mathrm{n}=1}^{\mathrm{N}} \gamma_{\mathrm{n}} \operatorname{revenues}_{\mathrm{i}, \mathrm{j}, \mathrm{k}, \mathrm{n}}+\varepsilon_{\mathrm{i}, \mathrm{j}, \mathrm{k}}
\end{aligned}
$$

We include IPO fixed effects to control for any unobserved drivers of normalized rationing that are common to all investors in a given IPO, and bank fixed effects to control for any unobserved polices that impact on all investors with the same bank. ${ }^{30}$ Because our dataset contains more than one book per IPO for some IPOs, we cluster standard errors at the IPO level. ${ }^{31}$

Starting with bid characteristics, the size of an order may be an important factor in allocation. Larger orders may provide certainty to the issuer that the IPO will be successful or may help attract other investors by certifying the quality of the IPO. On the other hand, issuers may prefer to avoid a concentrated shareholder base. We proxy for this effect by including in our regression dummy variables for the first and second quartile of the bid size distribution in an IPO (largest and large bids, respectively). We test whether information being revealed through the

\footnotetext{
${ }^{30}$ In the next section, we report regressions that also include investor and bank-investor fixed effects.

${ }^{31}$ We cluster standard errors at the IPO level to account for the fact that books for the same IPO are not independent observations. The results are qualitatively unchanged if we only include one book per IPO, using the book that includes the largest number of bids.
} 
order book is a driver of allocation by including several dummy variables in the regressions. Price sensitive bids are either limit bids or step bids. Money bids are those expressed as a money amount rather than as a number of shares. Early bids may provide issuers with more useful information and certainty than bids submitted late in the bookbuilding period. The early bid dummy variable equals one if a bid is in the first quartile of all bids ordered by time. Revised bids are bids in which quantity, price, or type was changed from the initial bid.

Regarding bidder characteristics, investors may express information on pricing not only through their bidding behavior but also through meetings with the issuer. Meeting is a dummy variable that equals one if an investor participated in one of the presentations and meetings during the bookbuilding roadshow. We also create a pilot fishing dummy variable that equals one if an investor takes part a meeting held before the intention to float is announced which are used by investment banks and issuers as an early gauge of demand for the IPO.

We proxy for an investor's overall activity in the IPO market by including a frequent bidder dummy that equals one for the most active quartile of investors and a one-time bidder dummy for those investors who participate in only one IPO in our sample. The second variable might capture individual investors who could receive special treatment from issuers or investment banks for reasons not observable to us, e.g. 'family and friends'.

To test whether revenues generated by investors for the bookrunner influence normalized rationing, for each IPO we group investors in quartiles according to the total revenues they generate for the bookrunner in the year of the IPO. We then include revenue quartile dummy variables in the regression $\left(1^{\text {st }}\right.$ revenue quartile, $2^{\text {nd }}$ revenue quartile, etc.). Those investors who have no revenues with the bookrunner are the omitted control group. We use revenue quartiles, rather than the absolute revenues received, for two reasons. First, although the information requested from the banks was in respect of 'total revenues received in each year for all services provided to this investor', it is likely that some banks were more inclusive than others in computing overall revenues. Therefore, the relative revenues of investors within a bank are likely to be more accurately measured than differences in revenues between banks. By using quartile rankings we address this issue. Second, there may be concerns about the strict linearity of the relationship between revenues and allocations, not least because some of the bank-investor 
revenues are very large. Of course, if banks do indeed link allocations in a simple linear way to absolute revenues, then our approach of focusing on the ranking of investors for a given bank will tend to under-state the results. ${ }^{32}$

\section{B. $\quad$ Pooled Results}

Table 6 shows regressions results for the whole sample of IPOs. We also analyze the sample in two further ways: whether or not the issuer employed a corporate finance advisor, and (for a subsample of the investors for whom we have a classification) whether the results differ between long-only and hedge funds.

Our baseline model (column 1) analyzes the determinants of allocation, excluding investor revenues. In this way, we replicate as far as possible earlier studies. Starting with bid characteristics, we find that the largest quartile of bids receives a relative allocation 0.26 higher (after normalizing for their higher bid size) than the smallest 50\% of bids. The second largest quartile of bids receives around 0.14 higher relative allocation (first column of Table 6). These results are of similar magnitude to those reported in Cornelli and Goldreich (2001).

Bids that include a price limit may be regarded as more informative than those that only specify a quantity (and will accept the resultant issue price). In the overall sample, we find only a modest impact from submitting a price sensitive bid: relative allocation increases by around 0.07. The effect of money bids on normalized rationing is insignificant. Bid revisions and early bids do not affect normalized rationing in a consistent way. In most specifications the impact of bidding early appears to be negative on normalized rationing, although the results are only occasionally significant. Visual inspection of the data suggests that bid revisions and timing of bids are not necessarily driven by fundamental reasons, but often by institutional constraints, e.g. investors simply adding orders to the book whenever they receive them from their own end clients.

Much stronger results are found for the impact of attending meetings, both during the bookbuilding and in any prior pilot-fishing. Frequent bidders also receive higher relative allocations, in line with previous research, as do one-time bidders. This latter is consistent with

\footnotetext{
${ }^{32}$ We show results with alternative specifications of the revenue variable, including using the revenue share of investor i with bank j, in the Internet Appendix. The results are qualitatively similar when we use different revenue variables.
} 
these investors (such as friends and family) being awarded shares for other reasons specific to the transaction.

Our results so far confirm the findings of previous studies but with a far larger, and comprehensive, dataset. Investors who submit bids which may be considered informative (in particular price sensitive bids and large bids), and those whose behavior may be considered informative (by frequent participation in IPOs and attendance at meeting) are rewarded with higher allocations. These findings are in line with information revelation theories of bookbuilding.

Next, in column 2, we add investor revenue quartiles to the baseline regression. There is little impact on the size or significance of the bid price sensitivity and meetings variables. Bid size effects fall slightly, but remain significant. This suggests that investor revenues are largely uncorrelated with these characteristics. We do find that the impact of being a frequent bidder in the IPOs of the bookrunner falls once we include investor revenues. Both variables measure, in different ways, the relationship between the investment bank and the investor. However, the revenue variables dominate in terms of the impact on allocations. Being placed in one of the top three revenue quartiles is associated with higher relative allocations than being in the bottom quartile or not producing any revenues for the investment bank. The coefficients are consistently significant and increasing in the investor's revenue position. The preferential allocations are sizeable: moving from the third revenue quartile to the top revenue quartile increases the relative allocation by 0.42 , which is a large impact given that the sample average normalized rationing is 0.78 (Table 5).

Therefore, across all banks and all IPOs, we find evidence that is consistent with both information revelation and quid pro quo theories of allocation. To gain a sense of the relative importance of the revenue variables (which point to quid pro quos) and the information variables (which point to information revelation) we may compare the coefficients in column 2 of Table 6. Moving from no revenues to the highest revenue quartile improves normalized rationing by 0.51 , while submitting a price-sensitive bid and attending a meeting during the bookbuilding improves normalized rationing by 0.30 .

Next we analyze, in columns (3) and (4) of Table 6, whether the results differ when a corporate finance advisor is engaged. The latter may help overcome any potential conflict of interest between issuer and investment bank. We find that the size effect is less pronounced for the IPOs with a corporate finance advisor. We also find a much larger (and more significant) impact of submitting price-sensitive bids in advised IPOs. This suggests that corporate finance 
advisors help to reward investors that submit limit or step bids rather than strike bids. Advised IPOs tend to be larger than unadvised IPOs (Table 2) and may generally be more complex and difficult to price, which could mean that price sensitive bids are more valuable in these deals. Controlling for the various bid and bidder characteristics, we find similar investor revenue effects in the advised and non-advised samples. Therefore, we do not find evidence that corporate finance advisors reduce significantly the impact of investor revenues on IPO allocations although, as noted earlier, they appear to increase allocations to investors who submit price sensitive bids, and their presence tends to increase the proportion of IPO fees that are discretionary.

We also explore whether long-only investors are treated differently to hedge funds. Traditional long-only funds are more likely to be longer term investors, and so are therefore more likely to form views as to the value of an issuing company, whereas hedge funds may participate in IPOs as an opportunity to make short-term trading profits. Previous research (Jenkinson and Jones (2009)) has found that being perceived as a long-term holder improves allocations. Therefore, for the subset of investors for whom we have a designation, we explore in columns (5) and (6) whether allocations vary by investor type. We find the revenue effects to be considerably stronger for long-only investors. We also find that bid size has a much smaller impact for hedge funds, which is only statistically significant for the largest quartile of bids. However, it is worth recalling (Table 5) that hedge funds tend to receive lower allocations, relative to their demand, than long-only investors: average normalized rationing for hedge funds is 0.55 compared with 1.08 for long-only investors. Relative to these average levels of rationing, the impacts of revenue on allocation are much more similar for the two investor types.

\section{Bank-by-Bank Regressions}

Up to this point, the results have been based on all IPOs. While we have included bank fixed effects, these only control for differences in the average level of normalized rationing across banks (which are minor) and so do not capture any differences in the way they conduct IPOs. In this section we investigate the extent to which allocation practices differ across banks, by estimating the models separately for the top nine most active bookrunners, with all remaining bookrunners included in a final group. 
Table 7 presents the results for our baseline regression. In order to maintain anonymity, we do not reveal the number of observations for each bank, and the order of the banks is random. ${ }^{33}$ Most coefficients are consistent, in sign and significance, with the pooled regressions discussed above, in particular those on the bid size and meetings variables (although the impact of pilot fishing meetings is much more variable, both in estimated impact and significance). However, we also see some heterogeneity across banks. In particular, the relevance of the price sensitivity of bids for the allocation decision seems to vary considerably by bank, with significant coefficients only being found in half of the regressions. This may explain the differing findings on this issue of Cornelli and Goldreich (2001) and Jenkinson and Jones (2004), which each used a dataset from a different (European) bookrunner.

Turning to the revenue variables we see a pattern that is remarkably consistent across most of the banks. For six banks the coefficients on the top revenue quartile of investors are similar - ranging from 0.56 to 0.72 . For bank eight and the group of smaller bookrunners, the coefficient is smaller but remains significant. For all these banks we find that relative allocations decline for the second and third revenue quartiles, although statistical significance becomes patchier. For bank four we find only a marginally significant revenue effect, and for bank six we find no evidence that investor revenues influence allocation at all. Nonetheless, for most leading IPO bookrunners, client revenues are clearly correlated with IPO allocations.

A further issue we explore is the temporal relationship between revenues and allocations. Banks supplied revenues from investors on a calendar year basis, and our empirical specifications to this point have used revenues in the calendar year of the IPO. If banks and investors see IPO allocations and broking revenues during a short period around the IPO as a single quid pro quo, revenues closer to the time of the IPO could be more important than those further away. Moreover, if the relationship between IPO allocations and previous broking revenues is different from the relationship between IPO allocations and subsequent broking revenues, this might

\footnotetext{
${ }^{33}$ The number of bids per bank varies from just under 3,000 to over 11,000, and the 'other' group of smaller banks includes around 5,500 observations.
} 
inform us about whether revenues or allocations are the trigger in such a quid pro quo. ${ }^{34}$ When we vary the timing of the revenue variable the coefficients are significant for all years, although they are slightly smaller in the years after the IPO than for the year of the IPO (the specification used in Table 6) and the year before. Considering the long-term relationships that exist between many investors and investment banks, which result in quite stable revenue flows over time, it is perhaps unsurprising that the precise timing of the revenues relative to the IPO makes little difference to the results (for details see Table IA.7 in the Internet Appendix).

\section{Is this evidence of a quid pro quo?}

The evidence that IPO allocations are higher for investors who generate more revenues for the bookrunner is consistent with the existence of a quid pro quo between bookrunners and investors. However, while we have controlled for observable proxies for information production - such as the type of bid and attendance at meetings during and before the IPO bookbuilding - we cannot observe the full range of communication between investor and bank. It seems plausible that investors with whom banks have closer relationships may have more, and perhaps more informative and truthful, contact. Therefore, it is possible that the correlation we have documented between revenues and allocations could be due to an unobservable characteristic of investors who generate large revenues.

Furthermore, bookbuilding theories, such as Benveniste and Spindt (1989) predict that investors who provide valuable information will earn information rents. It is possible that the generosity of allocations, which we have so far measured in terms of normalized rationing, does not, in fact, translate into higher expected profits for investors. In order to establish a quid pro quo in which both sides of the exchange are expressed in money terms, we need to take into account the expected underpricing of the IPOs in which an investor participates as well as the normalized rationing of that investor. More generous allocations in terms of normalized rationing

\footnotetext{
${ }^{34}$ See Reuter (2006) for evidence consistent with investors increasing commissions paid to underwriters after profitable IPOs; see Nimalendran et al. (2007) and Goldstein et al (2011) whose findings suggest that investors increase trading volumes with bookrunners before IPOs.
} 
could theoretically be offset if the IPOs in which an investor's normalized rationing was highest were also those in which the expected underpricing was the least.

We consider these two issues in this section, and then discuss the welfare implications of quid pro quos for the issuer.

\section{A. Unobserved Investor Characteristics}

To address the possibility that unobserved investor characteristics or actions lie behind our revenue variable, we introduce investor fixed effects and bank-investor fixed effects into the regressions. Investor fixed effects control for any drivers of normalized rationing that are constant for a given investor across different IPOs and banks. Examples might include providing particularly useful views on valuation on all IPOs, or being a large investor paying high brokerage fees to many banks. The investor fixed effects filter out this investor-specific effect, and so the coefficients capture only the characteristics that differ for the same investor from one IPO to another. For instance, having included investor fixed effects, the revenue variables will only capture the impact of variations in revenue quartiles across IPOs: if an investor is in the top revenue quartile for every IPO, this characteristic will be filtered out.

While investor fixed effects control for characteristics that are common to one investor across multiple IPOs with different banks, they do not control for characteristics which are specific to the relationship between one investor and one particular bank. For example, a bank which has a closer relationship with an investor may be better able to derive information from that investor which is useful in pricing IPOs, and may therefore decide to allocate them more shares. One reason for the strength of that relationship could be that the investor is a longstanding, active broking client of the bank. Therefore, we also re-run our baseline regressions including bank-investor fixed effects. In this case, the revenue variables will only capture variations in revenue quartiles of an investor in different IPOs run by the same bank. For example, an investor bidding in two IPOs run by the same bank may be in the top revenue quartile in the first IPO (alongside many low revenue investors) but in the third quartile in the second IPO (alongside many high revenue investors).

These models therefore need to be interpreted with care. If variations in a given investor's revenue ranking across IPOs, or across the IPOs of each bank, impact on allocation, this would support a quid pro quo interpretation for the results in the previous section. 
The results are shown in Table 8. Investor fixed effects are included in the model in column 1. The R-squared of the regression increases by about 40 percentage points compared with the baseline regression, i.e. $40 \%$ of the variation in normalized rationing is driven by characteristics specific to an investor. The bid-size quartile dummies are negative in contrast to the regressions without investor fixed effects, but only the coefficient for the largest bid-size quartile is statistically significant. This can be interpreted as follows: holding investor size constant (using the fixed effects) the additional impact of putting in a very large bid is actually negative and such large bids (by that investor) are penalized. ${ }^{35}$

Turning to the investor revenue variables, we find a positive and, for the first two revenue quartiles, significant relationship with normalized rationing when including investor fixed effects. As before, the size of the coefficients declines by revenue quartile. Overall the effects are smaller than in the regressions without fixed effects, which is to be expected since the revenue coefficients in this specification only capture the variation in revenue quartiles across IPOs. Therefore, for a given investor - whether particularly informed, communicative, helpful, large or small - variations in their revenue relationships across IPOs affect the allocation they receive.

Investor-bank fixed effects are included in column (2). The coefficients on the information variables are similar, in their economic and statistical significance, to those in the previous model including investor fixed effects. The top two revenue quartile variables are significant, positive, and increasing in revenues, implying that an investor who participates in different IPOs with a given bank will tend to receive a higher allocation in the IPO in which it is more important to the bank in revenue terms.

\section{B. $\quad$ Expected Profitability}

To this point we have focused on the determinants of IPO allocations, but we have not yet established the extent to which investors profit from such allocations. We explore this question in two ways. First, we analyse whether there are differences in allocation between hot and cold IPOs. Recall that we designate IPOs as hot if they become fully subscribed (at the lower end of the initial price range) more quickly than the median IPO. This measure gives an early indication

\footnotetext{
${ }^{35}$ The bid size variable combined with investor fixed effects can be thought of as a measure of aggressiveness. The negative sign may reflect the bookrunner's judgement that such bids are opportunistic rather than informative.
} 
of the "success" of the IPO, and is communicated to the market by the investment bank to stimulate more demand. It seems likely that investors particularly value allocations of hot issues, which would be expected to perform well in the aftermarket. This is, therefore, an informal heuristic measure of expected rents associated with allocations. Second, we adopt a more formal approach by estimating a model of expected underpricing which we combine with allocations to estimate the expected profitability of each investor's allocation. We then analyse whether proxies for information revelation and/or investor revenues are related to expected profits.

In columns (1) and (2) of Table 9 we split the sample into hot and cold IPOs. We find that the coefficients on the revenue quartile variables in hot IPOs are around twice the size of those in cold IPOs. A similar pattern of results is found for the impact of attending meetings. Pricesensitive bids are only marginally significant in hot IPOs. When we control for investor fixed effects, in columns (3) and (4), we find that that investor revenue effects, meetings variables, and size effects are statistically significant only for the hot IPOs. For the cold IPOs, the only significant variable is bidding early, which has a small and positive effect on allocation. None of the other information-related variables or the revenue variables impact on allocation, having controlled for investor fixed effects. These results suggest that changes in investor revenue rankings across IPOs have an impact on allocation only in the hot IPOs. It seems likely (although not certain, as the issue price might adjust) that investors would expect hot issues to be more underpriced, in which case the preferential allocations of hot issues to the higher revenue investors would also result in them earning higher expected rents.

To explore this further we estimate the expected profitability of bids. We examine expected, rather than ex-post profitability, because neither the investors nor the banks have perfect information about the future price of the shares at the end of bookbuilding. The expected gain of each investor is based on that investor's allocation and on the expected underpricing, with the latter calculated from the fitted values of the following regression ${ }^{36}$ :

\footnotetext{
${ }^{36}$ The specification is based on the underpricing regressions in Abrahamson et al. (2011).
} 


$$
\begin{aligned}
\text { Underpricing }=\alpha & \left.+\beta_{1} * \text { hot }+\beta_{2} * \sigma(\text { index })+\beta_{3} * \text { mean(index return }\right) \\
& +\beta_{4} * \text { advisor }+\beta_{5} \text { issuer industry }+\beta_{6} * \ln (\text { deal value }) \\
& +\beta_{7} * \text { price range revision }+\beta_{8} * \text { venture capital } \\
& +\beta_{9} * \text { quarter dummy }+\beta_{10} * \text { bank dummy }+\mathrm{u}_{\mathrm{i}}
\end{aligned}
$$

where underpricing is the ratio of the market price at the end of the first trading day and the issue price, hot is a dummy that takes value one if the IPO is above the median in terms of time till full subscription; $\sigma$ (index) and mean(index return) are the standard deviation and the average returns on a benchmark index ${ }^{37}$ in the 30 day period prior to the IPO; advisor is a dummy variable that takes value one if there was a corporate financial advisor present; issuer industry is a dummy variable for the Dealogic issuer industry classifications; price range revision is a dummy variable that takes value one if the price range was revised during the bookbuilding process; venture capital is a dummy that takes value one if the seller is a venture capital firm. All variables should be known to the investors before bookbuilding ends. Having estimated expected underpricing using this regression (which we report in Internet Appendix Table IA.4), we then calculate expected profitability as the number of shares to be allocated times the expected return on the first trading day divided by the size of the bid.

The results of the profitability regressions using expected underpricing are shown in Table 10. In the baseline regression (column 1) without investor fixed effects or the revenue variables, large bids, price-sensitive bids, and frequent bidders are significant determinants of expected profitability. This is in line with our findings on normalized rationing in section $3 \mathrm{~B}$. The greatest difference is that the meeting and pilot fishing variables had a significant impact on allocations, whereas we find no impact on expected profitability. When we introduce the revenue variables (column 2), the pattern is again similar to that for normalized rationing: the top three revenue dummies are positive, significant, and economically important, with the impact of being in the top quartile of investors by revenue increasing expected profitability by 0.49 . Once we include the revenue variables, the significance of the other bid and bidder characteristics does not

\footnotetext{
${ }^{37}$ As classified by Thomson Reuter's Datastream.
} 
change except for the frequent bidder variable, which becomes insignificant, suggesting that high revenue investors are also frequent participants in IPOs.

These findings support the earlier results for hot and cold IPOs, and show that high revenue investors receive more profitable allocations than low or no revenue investors, after controlling for observable information-related proxies. To address the possibility that informative but unobserved characteristics of bidders are driving these results, we also run the profitability regressions including investor and investor-bank fixed effects (columns 3 and 4 of Table 10). With investor fixed effects the revenue variables are increasing in revenues and significant for the top two quartiles, with a coefficient on the top revenue quartile of 0.27 . When we introduce investor-bank fixed effects, however, the revenue variables follow the same pattern but are insignificant.

These weaker results when including bank-investor fixed effects are not entirely surprising. First, while bookrunners have a high level of influence over IPO allocations, they have much less control over the profits earned by investors. Although there is clear evidence that the high revenue investors receive better allocations of (ex-ante) hot IPOs, the ability to predict the initial underpricing is limited. Second, our measure of profitability measures out-turn profits relative to the amount bid. As noted by Cornelli and Goldreich (2001), the fact that some investors are informed does not mean that they are able to choose the winning issues. The same goes for highly profitable investors (who may or may not be informed). Even if investment banks have quid pro quo intentions, their ability to achieve this outcome would be limited by their lack of control over investor bidding behavior and errors in predicting underpricing.

\section{The welfare implications of quid pro quos}

The link which we establish between IPO allocations, expected profitability of bids, and revenues points strongly to a quid pro quo. However, as noted earlier, banks' conflict of interest policies, which are required by the financial regulators, generally prohibit any such arrangements. The rationale for such policies is to prevent bookrunners from making IPO allocations against the interests of the issuer, for example to high-revenue clients who then flip their shares when trading begins, placing downward pressure on the stock.

However, quid pro quo arrangements are not necessarily welfare destroying. One benign explanation of the allocation-revenue relationship is that an investor may direct a larger share of its revenues to an investment bank to gain entry to a 'coalition' of investors which is formed to 
support the IPOs of that bookrunner (see Gondat-Larralde and James (2008)). Coalition investors implicitly agree to participate in all of that bookrunner's IPOs, rather than picking and choosing between them (or 'lemon-dodging'), and they are rewarded by an expected level of underpricing across them all. This would be in the issuer's interest if it increased the certainty that the IPO is completed. However, this model is not supported by our evidence. We show in section 4.A that the allocation-revenue relationship remains even when controlling for bank-investor fixed effects, which should capture existing coalitions. ${ }^{38}$ Searching more directly for the existence of coalitions, we find that only $0.22 \%$ of investors (i.e. 47 ) invested in more than $80 \%$ of the IPOs of any one bookrunner, and that $98.5 \%$ of investors invested in under half of any bank's IPOs. This suggests that investors do pick and choose IPOs run by the same bookrunner.

An alternative benign explanation for quid pro quos is that banks allocate shares more generously to their high-revenue clients only when all the relevant pricing information has been extracted from informed investors, at which point the choice of investor to allocate is indifferent from an informational point of view. In competitive IPO markets underwriters would then be forced to pass on to the issuer at least some of the benefits of the incremental broking revenues, which could be done through lower IPO fees or reduced underpricing. ${ }^{39}$

As we show in Table 7, the allocation to high-revenue clients varies little between bookrunners, making it difficult to quantify the impact that additional revenues might have on fees and underpricing. However, it is worth noting that fees and underpricing in our sample are comparatively low (Table 2 and Table 5) making it plausible that IPOs managed from the U.K. were, during this time, in a competitive equilibrium in which at least some of the quid pro quos

\footnotetext{
${ }^{38}$ It is possible that the positive revenue coefficients in the bank-investor fixed effect regressions of Table 8 are driven by investors trying to enter a coalition by channeling additional broking revenues to an underwriter (as opposed to being in a coalition already). However, there were only 10 investors who participated in all of the next 10 IPOs of a given bank after moving into the top two revenue quartiles with that bank (out of a total of about 1,800 investors moving into the top two quartiles).

${ }^{39}$ If the bookrunner passed on the benefits of additional revenues through underpricing, allocations would, other things equal, be less profitable for investors. We should then expect the bookrunner to use more generous levels of normalized rationing to compensate preferred investors. For a discussion of profit sharing between bookrunners and investors and underpricing see Hao (2007).
} 
were in fact passed on to issuers. The same may not be true, however, of other IPO markets or for other time periods. For example, IPOs in the U.S. during the same period had greater underpricing as well as higher, less variable, and non-discretionary, fees, and the equilibrium may, therefore, have been different. Research into the role of quid pro quos in the U.S. market would be needed to explore whether the contrasting outcomes in the U.S. and in our sample of IPOs could be explained by different revenue-allocation relationships in the two markets. In general, preferential allocation of underpriced shares is more likely to be indicative of agency problems when fees and underpricing are high. The most striking example of such a period was the 1999-2000 dot com period in the U.S., when $\$ 67$ billion was left on the table and a fee of exactly $7 \%$, with no discretionary element, was charged for $82 \%$ of these IPOs. ${ }^{40}$ The subsequent investigations and lawsuits have shown that agency problems relating to IPO allocations were rife during this period.

\section{Conclusions}

This paper draws on a unique data set to test the determinants of IPO allocations. We have access not only to the complete books of demand and allocation in IPOs but also to details of revenues earned by IPO syndicate banks from the investors who participate in IPOs. This allows us to test the extent to which IPO allocations are related to information revelation by investors, and also to test whether there is a quid pro quo between IPO allocations and revenues - for which the evidence has, up to now, been indirect. The data in our study were gathered as part of an investigation by the U.K. financial regulator, and covers all investment banks operating in the U.K. - which includes all the major international banks - and all IPOs managed from the U.K. over the period January 2010 to May 2015. The IPOs in our study represent some three-quarters of total IPO volumes for issuers in Europe, the Middle East, and Africa over this period.

We find evidence consistent with syndicate banks making favorable allocations to investors who provide them with information likely to be useful in pricing the IPO. Investors who submit price-sensitive bids, and, in particular, those who attend meetings with the issuer during

\footnotetext{
${ }^{40}$ These figures are from Jay Ritter's website.
} 
the IPO process, are favored in allocations. Our findings therefore lend support to information revelation explanations for IPO allocations and underpricing.

At the same time, bookrunners make favorable allocations to investors from whom they generate the greatest revenues elsewhere in their business, notably through brokerage commissions. Allocations increase steadily with investor revenue rankings, and eventually dominate the estimated impact of our proxies for information generation. Thus, investors in the top quartile of the bookrunners' clients by revenues receive allocations, relative to the amount they bid, around $60 \%$ higher than those received by investors who are not clients of the bookrunner. The relationship between revenues generated and allocations is mainly associated with 'hot' IPOs. These results hold for most of the leading investment banks, but not all.

Before interpreting this as a quid pro quo, we explore alternative explanations for the relationship between investor revenues and allocations. Investors who generate large revenues may have greater expertise and efficiency in producing information, and may have closer relationships with investment banks that result in more, and more truthful, revelation of information. Only some characteristics of bidders and their behavior during the IPO can be observed. We control for unobserved investor fixed effects, and also more specific investor-bank fixed effects, and find that changes in investor revenue rankings have a significant, and economically large, impact on allocations. We also find that these allocations result in higher expected profits for investors who generate the most revenue. These tests provide support for the quid pro quo interpretation.

The evidence in this paper relates to IPOs managed from the U.K during a particular period, which raises the question whether our results generalize to other markets, notably the U.S., and to other time periods. The same banks and investors were involved in U.S. IPOs in this period, bookbuilding techniques were broadly similar in both markets, and the scope for quid pro quo arrangements also existed in the U.S. market. However, there were important differences between the IPOs in our sample and those managed out of the U.S. at that time: U.S. IPO fees were higher, they did not have a discretionary element, and underpricing was wider. It is perhaps the case that, in the IPOs in our sample, more of the benefits of quid pro quos were being passed from the bookrunner to the issuer in the form of lower IPO costs, and that this was less the case for U.S. IPOs. A comparison with the U.S. market in this respect would represent an interesting opportunity for future research. 
The results in this paper suggest that regulators may want to monitor the IPO market more closely. This is already happening in Europe as part of the revised Markets in Financial Instruments Directive (MiFID II) which introduces a requirement for investment banks to justify final allocations made to each investor client. Our research has been used to underpin the European Securities and Markets Authority's guidance on this requirement, which seeks to ensure that investment banks justify both their largest allocations and the allocations with the highest normalized rationing (using the measure we employ in our paper). This should have the effect of allowing banks continued discretion in allocation while requiring greater transparency for the issuer and regulators. 


\section{References}

Abrahamson, Mark, Tim Jenkinson and Howard Jones, 2011, Why don't U.S. issuers demand European fees for IPOs? Journal of Finance 66, 2055-2082.

Benveniste, Lawrence M., and Paul A. Spindt, 1989, How investment banks determine the offer price and allocation of new issues, Journal of Financial Economics 24, 213-232.

Benveniste, Lawrence M. and Wilhelm, William J., 1990, A comparative analysis of IPO proceeds under alternative regulatory environments, Journal of Financial Economics 28, 173-207.

Caglio, Cecilia, Kathleen Weiss Hanley, and Jennifer Marietta-Westberg. 2013. Going Public Abroad, FEDS Working Paper No. 2013-68

Cornelli, Francesca and David Goldreich, 2001, Bookbuilding and strategic allocation, Journal of Finance 56, 2337-2369.

Chambers, David and Elroy Dimson, 2009, IPO Underpricing over the Very Long Run, Journal of Finance 64, 1407-1443.

Doidge, Craig, A. Karolyi, and R. Stulz, 2013, The U.S. left behind? Financial globalization and the rise of IPOs outside the U.S. Journal of Financial Economics, 110, 546-573.

FCA, 2014, Wholesale sector competition review: call for inputs, July. https://www.fca.org.uk/your-fca/documents/market-studies/wholesale-sector-competitionreview--call-for-inputs

FCA, 2015a, Wholesale sector competition review, February. www.fca.org.uk/news/fs15-02wholesale-sector-competition-review-2014-15

FCA, 2015b, Investment and corporate banking market study: terms of reference, May. Www.fca.org.uk/your-fca/documents/market-studies/ms15-1-1-investment-and-corporatebanking-market-study-tor

FCA, 2015c, Transaction Reporting User Pack (TRUP), Version 3.1, February, https://www.fca.org.uk/static/documents/finalised-guidance/fg15-03.pdf

FCA, 2016, Investment and corporate banking market study Interim report, April 2016, https://www.fca.org.uk/static/documents/market-studies/ms15-1-2-interim-report.pdf

Goldstein, Michael A., Irvine, Paul J. And Puckett, W. Andy, 2011, Purchasing IPOs with Commissions, Journal of Financial and Quantitative Analysis, Volume 46, Issue 051193 1225. 
Gondat-Larralde, Celine and James, Kevin R., 2008, IPO Pricing and Share Allocation: The Importance of Being Ignorant, Journal of Finance 63(1), 449-478.

Hao, Qing, 2007, Laddering in initial public offerings, Journal of Financial Economics 85(1), 102-122.

Jenkinson, Tim and Howard Jones, 2004, Bids and allocations in European IPO bookbuilding, Journal of Finance 59, 2309-2338.

Jenkinson, Tim and Howard Jones, 2009, IPO pricing and allocation: a survey of the views of institutional investors, Review of Financial Studies 22, 1477-1504.

Jenkinson, Tim and Alexander Ljungqvist, 2001, Going Public, $2^{\text {nd }}$ Edition, Oxford: Oxford University Press.

Jenkinson, Tim, Alan Morrison and William Wilhelm, 2006, Why are European IPOs so rarely priced outside the indicative price range? Journal of Financial Economics 80, 185-209.

Liu Xiaoding and Jay Ritter, 2010, The economic consequences of IPO spinning, Review of Financial Studies 23, 2024-2059.

Ljungvist, Alexander, Tim Jenkinson and William Wilhelm, 2003, Global integration in primary equity markets: the role of U.S. banks and U.S. investors, Review of Financial Studies 16, 63-99.

Nimalendran, Mahendrarajah, Jay Ritter and Donghang Zhang, 2007, Do today's trades affect tomorrow's IPO allocation? Journal of Financial Economics 84, 87-109.

Reuter, Jonathan, 2006, Are IPO allocations for sale? Evidence from mutual funds, Journal of Finance 61, 2289-2324.

Ritter, Jay, 2011, Equilibrium in the Initial Public Offerings Market," Annual Review of Financial Economics, 3, 347-374.

Ritter, Jay and Donghang Zhang, 2007, Affiliated mutual funds and the allocation of initial public offerings, Journal of Financial Economics 86, 337-368.

Xiaohui Gao, Ritter, Jay R., and Zhangyan Zhu, 2013, Where have all the IPOs gone? Journal of Financial and Quantitative Analysis 48, 1663-1692. 


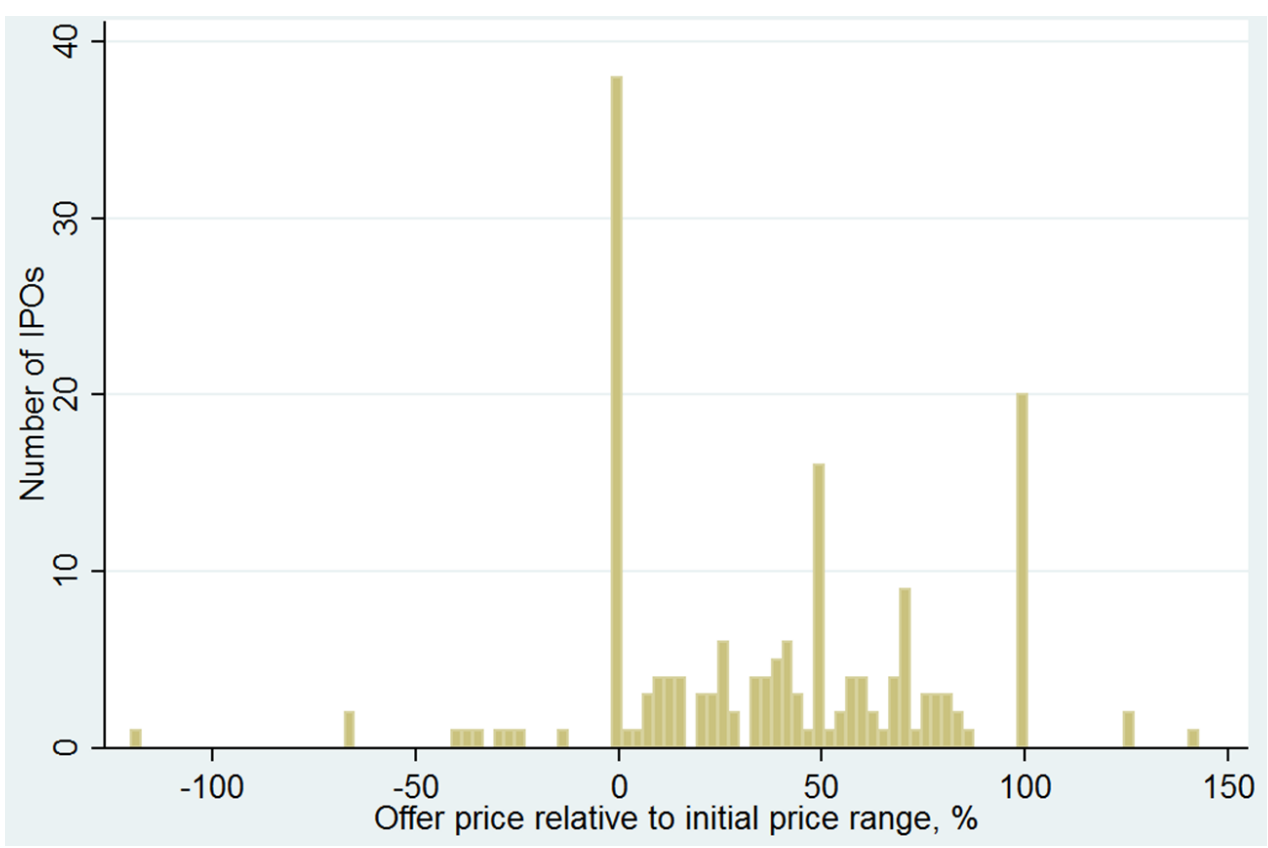

Figure 1. Number of IPOs by ratio of offer price to initial price range. Source: Dealogic database and bank responses to the Investment and Corporate Banking Market Study. 
Table 1: Transactions by year, primary exchange, and issuer country

This table shows the number of IPOs by year (Panel A), by the primary exchange on which they were listed (Panel B), and by the principal country of origin of the issuing company (Panel C). For each panel Median size and total value refer to IPO proceeds, including both primary and secondary shares.

\begin{tabular}{|c|c|c|c|}
\hline \multicolumn{4}{|c|}{ Panel A: IPOs by year } \\
\hline Year & Number & Median size $(\$ \mathrm{~m})$ & Total value (\$bn) \\
\hline 2010 & 38 & 517.26 & 34.54 \\
\hline 2011 & 21 & 383.01 & 21.19 \\
\hline 2012 & 17 & 289.22 & 10.82 \\
\hline 2013 & 38 & 512.66 & 25.01 \\
\hline 2014 & 77 & 497.01 & 46.14 \\
\hline Jan-May 2015 & 29 & 369.27 & 21.75 \\
\hline Total & 220 & 476.92 & 159.45 \\
\hline \multicolumn{4}{|c|}{ Panel B: IPOs by primary exchange } \\
\hline Exchange & Number & Median size $(\$ m)$ & Total value (\$bn) \\
\hline London & 74 & 384.06 & 42.57 \\
\hline Frankfurt & 22 & 565.61 & 14.88 \\
\hline Milan & 13 & 487.08 & 6.50 \\
\hline Warsaw & 12 & 442.23 & 8.78 \\
\hline Paris & 11 & 869.44 & 7.53 \\
\hline Nasdaq & 9 & 71.03 & 0.78 \\
\hline Copenhagen & 7 & 575.59 & 6.12 \\
\hline Johannesburg & 7 & 199.61 & 1.96 \\
\hline Amsterdam & 6 & 1218.58 & 8.23 \\
\hline Madrid & 6 & 1196.31 & 10.79 \\
\hline Other & 33 & 469.40 & 21.53 \\
\hline Multiple exchanges & 20 & 585.40 & 29.79 \\
\hline Total & 220 & 476.92 & 159.45 \\
\hline \multicolumn{4}{|c|}{ Panel C: IPOs by issuer country } \\
\hline Country & Number & Median size $(\$ \mathrm{~m})$ & Total value (\$bn) \\
\hline UK & 57 & 392.28 & 33.11 \\
\hline Germany & 23 & 538.44 & 14.94 \\
\hline Russian Federation & 18 & 462.99 & 12.21 \\
\hline Italy & 15 & 505.62 & 12.41 \\
\hline France & 12 & 887.03 & 9.56 \\
\hline Poland & 11 & 464.07 & 8.70 \\
\hline Denmark & 8 & 534.45 & 6.35 \\
\hline Spain & 8 & 1196.31 & 13.27 \\
\hline Netherlands & 7 & 1150.86 & 7.45 \\
\hline South Africa & 7 & 199.61 & 1.96 \\
\hline Switzerland & 7 & 804.68 & 14.73 \\
\hline Other & 47 & 379.14 & 24.77 \\
\hline Total & 220 & 476.92 & 159.45 \\
\hline
\end{tabular}




\section{Table 2: Syndicate structure, fees, and the prevelance of corporate finance advisors}

Panel A provides summary information on the syndicate structure for the 220 IPOs in our sample. We distinguish between IPOs with and without a corporate finance advisor. Bookrunners are all bookrunning banks as reported by Dealogic. Active bookrunners are the subset of banks that are designated as active in the allocation process, as explained in Section 2. Syndicate members are counted as bookrunners only if they were active bookrunners. Panel B summarizes IPO fees for 188 of the IPOs where this information was available. Where the fee was split into a fixed fee and a discretionary fee, the 'Total fee' column sums the fixed fee and the amount of discretionary fee actually paid to the banks subject to the FCA's information request. The discretionary fee is also presented separately.

\begin{tabular}{|c|c|c|c|c|c|c|}
\hline \multicolumn{7}{|c|}{ Panel A: Syndicate structure } \\
\hline & Mean & Median & Min & $\operatorname{Max}$ & $\begin{array}{c}\text { Median IPO } \\
\text { proceeds } \\
\text { USD m }\end{array}$ & $\begin{array}{l}\text { Number } \\
\text { of IPOs }\end{array}$ \\
\hline Total syndicate size, whole sample & 5.1 & 4.50 & 1 & 19 & 477 & 220 \\
\hline - IPOs with advisors & 5.6 & 5 & 1 & 19 & 650 & 71 \\
\hline - IPOs without advisors & 4.9 & 4 & 1 & 19 & 392 & 149 \\
\hline Bookrunners, whole sample & 3.38 & 3 & 1 & 11 & & \\
\hline - IPOs with advisors & 3.68 & 3 & 1 & 9 & & \\
\hline - IPOs without advisors & 3.24 & 3 & 1 & 11 & & \\
\hline Active bookrunners, whole sample & 1.69 & 2 & 1 & 4 & & \\
\hline - IPOs with advisors & 1.83 & 2 & 1 & 3 & & \\
\hline - IPOs without advisors & 1.62 & 2 & 1 & 4 & & \\
\hline \multicolumn{7}{|c|}{ Panel B: Fees } \\
\hline & $\begin{array}{l}\text { Mean } \\
\text { total } \\
\text { fee }\end{array}$ & $\begin{array}{c}\ldots \text { of } \\
\text { which } \\
\text { discret- } \\
\text { ionary }\end{array}$ & $\begin{array}{l}\text { Median } \\
\text { total fee }\end{array}$ & $\begin{array}{c}\text {.. of } \\
\text { which } \\
\text { discret- } \\
\text { ionary }\end{array}$ & $\begin{array}{l}\text { Median } \\
\text { IPO } \\
\text { proceeds } \\
\text { USD m }\end{array}$ & $\begin{array}{l}\text { Number } \\
\text { of IPOs }\end{array}$ \\
\hline All IPOs with fee information & $2.77 \%$ & $0.45 \%$ & $2.50 \%$ & $0.34 \%$ & 385 & 188 \\
\hline - With advisors & $2.41 \%$ & $0.71 \%$ & $2.45 \%$ & $0.55 \%$ & 563 & 51 \\
\hline - Without advisors & $2.90 \%$ & $0.36 \%$ & $2.50 \%$ & $0.16 \%$ & 348 & 137 \\
\hline
\end{tabular}




\section{Table 3: Investors' bidding behavior}

The table shows bid characteristics over the full sample as well as over hot issues and cold issues. Hot (cold) IPOs are below (above) the median of the time till full subscription at the lower end of the initial price range. Price sensitive bids are those in which the bidder sets a maximum price she/he is willing to pay. Step bids are bids in which a bidder sets multiple price limits for different amount of shares. We denote as 'strike bids' those bids that do not have a price limit and as 'money bids' all bids that are strike bids and are expressed in currency, not in number of shares. Revised bids refer to revisions in price, quantity, or type of bid. Meetings are in most cases one-on-one meetings between issuers and investors. Pilot fish meetings are meetings that took place before the IPO was announced.

\begin{tabular}{lcccccc}
\hline & \multicolumn{2}{c}{ All issues } & \multicolumn{2}{c}{ Hot issues } & \multicolumn{2}{c}{ Cold issues } \\
& Mean & Median & Mean & Median & Mean & Median \\
\hline Price sensitive & $46.6 \%$ & $48.7 \%$ & $30.0 \%$ & $23.1 \%$ & $55.6 \%$ & $57.5 \%$ \\
$\ldots$ step bids & $9.6 \%$ & $8.9 \%$ & $7.1 \%$ & $5.3 \%$ & $10.7 \%$ & $9.8 \%$ \\
Strike bids & $54.3 \%$ & $51.5 \%$ & $71.2 \%$ & $77.1 \%$ & $45.0 \%$ & $42.7 \%$ \\
$\ldots$ money bids & $36.1 \%$ & $31.2 \%$ & $50.1 \%$ & $55.5 \%$ & $33.1 \%$ & $28.2 \%$ \\
Median number of bids & & 140 & & 363 & & 97 \\
Revised bids & $42.0 \%$ & $42.2 \%$ & $39.2 \%$ & $40.1 \%$ & $44.3 \%$ & $44.6 \%$ \\
Attended at least one meeting & $20.4 \%$ & $18.9 \%$ & $21.9 \%$ & $20.1 \%$ & $20.6 \%$ & $21.5 \%$ \\
Attended pilot fishing & $6.4 \%$ & $4.2 \%$ & $6.1 \%$ & $4.7 \%$ & $7.2 \%$ & $5.8 \%$ \\
\hline
\end{tabular}

\section{Table 4: Investment bank revenues from investors}

In this table the total revenues derived from investors, across all banks, are presented by year. In addition, annual totals for the top five banks by revenue are also presented, as is the number of investor clients for each bank. Revenues are global and span all services provided by the investment bank to the investor. The revenue and number of clients by individual bank are presented in ranges to preserve anonymity.

\begin{tabular}{lccccccc}
\hline & 2010 & 2011 & 2012 & 2013 & 2014 & Average $\begin{array}{c}2010-2014 \\
\text { Total }\end{array}$ \\
\hline Total revenue (\$bn) & 31.7 & 41.0 & 37.7 & 38.2 & 38.5 & 37.4 & 187.1 \\
\hline $\begin{array}{l}\text { Top five banks by } \\
\text { revenue (\$bn) }\end{array}$ & 2010 & 2011 & 2012 & 2013 & 2014 & Total & $\begin{array}{c}\text { Revenue } \\
\text { clients }\end{array}$ \\
\hline Bank A & $9-10$ & $8-9$ & $7-8$ & $7-8$ & $7-8$ & $39-40$ & $1400-1500$ \\
Bank B & n.a. & $8-9$ & $7-8$ & $8-9$ & $8-9$ & $32-33$ & $500-600$ \\
Bank C & $6-7$ & $6-7$ & $5-6$ & $5-6$ & $5-6$ & $29-30$ & $2700-2800$ \\
Bank D & $5-6$ & $4-5$ & $4-5$ & $4-5$ & $4-5$ & $23-24$ & $500-600$ \\
Bank E & $3-4$ & $4-5$ & $3-4$ & $3-4$ & $3-4$ & $17-18$ & $1600-1700$ \\
\hline
\end{tabular}




\section{Table 5: Investor outcomes}

Panel A shows the level of subscription at the offer price, the offer price relative to the initial and revised price range (offer price minus lower end of range divided by the difference between upper and lower end of range), and the underpricing of the shares after one day of trading and after one week of trading (underpricing is the difference between secondary market closing price and offer price divided by the offer price). Panel B shows the average and median percentage of shares allocated by investor type and by revenue type. Panel $\mathrm{C}$ shows normalised rationing (the ratio of percent allotted to percent bid) by investor type and by revenue type.

\begin{tabular}{|c|c|c|c|c|c|c|}
\hline \multicolumn{7}{|c|}{ Panel A: Outcomes } \\
\hline & & \multicolumn{2}{|l|}{ Mean } & Median & Min & Max \\
\hline \multicolumn{2}{|l|}{ Subscription } & 4.5 & \multicolumn{2}{|c|}{2.6} & 1 & 28 \\
\hline \multicolumn{2}{|c|}{ Offer price relative to initial } & $40 \%$ & \multicolumn{2}{|c|}{$40 \%$} & $-120 \%$ & $140 \%$ \\
\hline \multicolumn{2}{|c|}{ Offer price relative to revised } & $50 \%$ & \multicolumn{2}{|c|}{$50 \%$} & $0 \% \%$ & $280 \%$ \\
\hline \multicolumn{2}{|c|}{ Underpricing 1st day } & $4.8 \%$ & \multicolumn{2}{|c|}{$3.8 \%$} & $-27.5 \%$ & $49.7 \%$ \\
\hline \multicolumn{2}{|c|}{ - with advisors } & $4.4 \%$ & \multicolumn{2}{|c|}{$3.7 \%$} & $-12.9 \%$ & $37.9 \%$ \\
\hline \multicolumn{2}{|l|}{ - without advisors } & $5.0 \%$ & \multicolumn{2}{|c|}{$3.8 \%$} & $-27.5 \%$ & $49.7 \%$ \\
\hline Underpricing 1st $\mathrm{W}$ & & $5.4 \%$ & & & $-22.3 \%$ & $51.7 \%$ \\
\hline - with advisors & & $4.9 \%$ & & & $-22.3 \%$ & $45.5 \%$ \\
\hline - without advisors & & $5.6 \%$ & & & -18.61 & $51.7 \%$ \\
\hline & & Pane & Total \% & ation & & \\
\hline & & & & & & aple \\
\hline & Mean & Median & Mean & Median & & Obs. \\
\hline - Hedge fund & $14.9 \%$ & $13.5 \%$ & $18.6 \%$ & $17.0 \%$ & & 8568 \\
\hline - Long only & $32.9 \%$ & $34.4 \%$ & $26.1 \%$ & $24.9 \%$ & & 8414 \\
\hline - Others & $52.1 \%$ & $47.4 \%$ & $55.8 \%$ & $51.6 \%$ & & 41321 \\
\hline Revenue quartile & & & & & & \\
\hline - no revenues & $43.2 \%$ & $29.4 \%$ & $48.3 \%$ & $39.4 \%$ & & \\
\hline - bottom quartile & $8.7 \%$ & $5.9 \%$ & $9.2 \%$ & $7.6 \%$ & & \\
\hline$-25-50$ & $15.2 \%$ & $14.2 \%$ & $11.5 \%$ & $11.3 \%$ & & \\
\hline$-50-75$ & $18.3 \%$ & $18.0 \%$ & $18.6 \%$ & $18.1 \%$ & & \\
\hline - top 25 & $33.0 \%$ & $32.4 \%$ & $23.7 \%$ & $22.2 \%$ & 27 & \\
\hline & & Pane & Normali & ning & & \\
\hline & & & & & & Full sample \\
\hline Type & & Mean & Median & Mean & Median & Mean \\
\hline - Hedge fund & & 0.55 & 0.54 & 0.66 & 0.64 & 0.63 \\
\hline - Long only & & 1.08 & 1.08 & 0.95 & 0.96 & 0.98 \\
\hline - Others & & 0.74 & 0.71 & 0.77 & 0.77 & 0.77 \\
\hline All & & 0.78 & 0.74 & 0.79 & 0.79 & 0.78 \\
\hline Revenue quartile & & Q1 - lowest & Q2 & Q3 & Q4 - highest & No revenues \\
\hline Normalised rationi & - mean & 0.67 & 0.79 & 0.96 & 1.16 & 0.71 \\
\hline - with advisors & & 0.63 & 0.78 & 0.89 & 1.17 & 0.65 \\
\hline - without advisors & & 0.69 & 0.79 & 0.99 & 1.15 & 0.74 \\
\hline
\end{tabular}




\section{Table 6: Determinants of allocation}

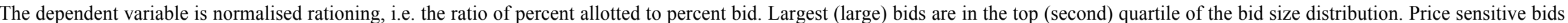

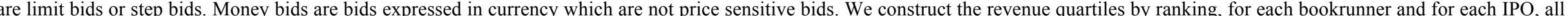

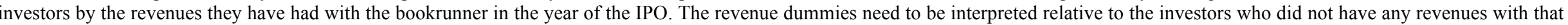

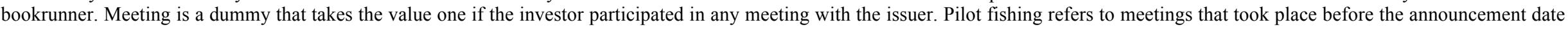

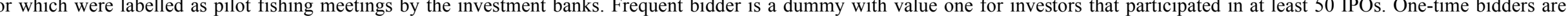

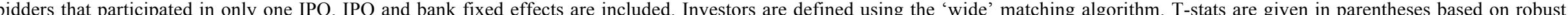
standard errors clustered at the IPO level.

\begin{tabular}{|c|c|c|c|c|c|c|}
\hline Explanatory variables & $\begin{array}{l}\text { Baseline } \\
\text { model } \\
(1)\end{array}$ & $\begin{array}{l}\text { Including investor } \\
\text { revenues } \\
(2) \\
\end{array}$ & $\begin{array}{l}\text { Advised } \\
\text { IPOs } \\
(3) \\
\end{array}$ & $\begin{array}{c}\text { Non-advised } \\
\text { IPOs } \\
(4) \\
\end{array}$ & $\begin{array}{c}\text { Long-only } \\
\text { investors } \\
(5) \\
\end{array}$ & $\begin{array}{l}\text { Hedge } \\
\text { funds } \\
(6)\end{array}$ \\
\hline Largest & $\begin{array}{c}0.256^{* * * *} \\
(8.31)\end{array}$ & $\begin{array}{c}0.192 * * * \\
\quad(5.86)\end{array}$ & $\begin{array}{c}0.170 * * * \\
(3.44)\end{array}$ & $\begin{array}{c}0.208 * * * \\
(4.71)\end{array}$ & $\begin{array}{c}0.398 * * * \\
(6.86)\end{array}$ & $\begin{array}{c}0.085^{* * * *} \\
(3.87)\end{array}$ \\
\hline Large & $\begin{array}{c}0.137 * * * \\
(4.86)\end{array}$ & $\begin{array}{c}0.117 * * * \\
\quad(4.29)\end{array}$ & $\begin{array}{c}0.107 * * \\
(2.65)\end{array}$ & $\begin{array}{c}0.126^{* * *} \\
(3.37)\end{array}$ & $\begin{array}{c}0.231 * * * \\
(6.31)\end{array}$ & $\begin{array}{l}0.024 \\
(1.05)\end{array}$ \\
\hline Price sensitive bid & $\begin{array}{c}0.072 * * \\
(2.46)\end{array}$ & $\begin{array}{c}0.069 * * \\
(2.41)\end{array}$ & $\begin{array}{c}0.116^{* * * *} \\
(3.84)\end{array}$ & $\begin{array}{c}0.031 \\
(0.68)\end{array}$ & $\begin{array}{c}0.159 * * * \\
(4.00)\end{array}$ & $\begin{array}{c}0.174 * * * \\
(6.53)\end{array}$ \\
\hline Money bid & $\begin{array}{l}-0.061 \\
(-1.61)\end{array}$ & $\begin{array}{l}-0.049 \\
(-1.32)\end{array}$ & $\begin{array}{l}-0.041 \\
(-1.25)\end{array}$ & $\begin{array}{l}-0.055 \\
(-0.89)\end{array}$ & $\begin{array}{l}0.046 \\
(0.91)\end{array}$ & $\begin{array}{c}0.071 * * * \\
(3.07)\end{array}$ \\
\hline Early & $\begin{array}{l}-0.036 \\
(-1.00)\end{array}$ & $\begin{array}{l}-0.027 \\
(-0.77)\end{array}$ & $\begin{array}{c}-0.052 * * \\
(-2.13)\end{array}$ & $\begin{array}{l}-0.009 \\
(-0.16)\end{array}$ & $\begin{array}{l}-0.025 \\
(-0.80)\end{array}$ & $\begin{array}{c}0.0642 * * * \\
\quad(3.61)\end{array}$ \\
\hline Revised bid & $\begin{array}{l}0.025 \\
(0.95)\end{array}$ & $\begin{array}{c}0.014 \\
(0.53)\end{array}$ & $\begin{array}{c}0.062 * * \\
(2.60)\end{array}$ & $\begin{array}{l}-0.023 \\
(-0.55)\end{array}$ & $\begin{array}{c}-0.102 * * \\
(-2.02)\end{array}$ & $\begin{array}{c}0.038 * * \\
(1.99)\end{array}$ \\
\hline Meeting & $\begin{array}{c}0.266 * * * \\
(11.93)\end{array}$ & $\begin{array}{c}0.235^{* * *} \\
(11.44)\end{array}$ & $\begin{array}{c}0.256^{* * * *} \\
(8.49)\end{array}$ & $\begin{array}{c}0.225 * * * \\
(7.82)\end{array}$ & $\begin{array}{c}0.290 * * * \\
(7.74)\end{array}$ & $\begin{array}{c}0.163 * * * \\
(5.77)\end{array}$ \\
\hline Pilot fishing & $\begin{array}{c}0.266^{* * *} \\
(4.45)\end{array}$ & $\begin{array}{c}0.244 * * * \\
(4.39)\end{array}$ & $\begin{array}{c}0.239 * * * \\
(3.36)\end{array}$ & $\begin{array}{c}0.253 * * * \\
(2.80)\end{array}$ & $\begin{array}{c}0.358 * * * \\
(2.67)\end{array}$ & $\begin{array}{c}0.161 * * * \\
(3.04)\end{array}$ \\
\hline Frequent bidder & $\begin{array}{c}0.224 * * * \\
\quad(6.85)\end{array}$ & $\begin{array}{c}0.077 * * * \\
(3.24)\end{array}$ & $\begin{array}{c}0.055^{*} \\
(1.73)\end{array}$ & $\begin{array}{c}0.092 * * * \\
(2.73)\end{array}$ & $\begin{array}{c}0.116^{* * *} \\
(3.25)\end{array}$ & $\begin{array}{c}0.050 * * * \\
(2.74)\end{array}$ \\
\hline One-time bidder & $\begin{array}{c}0.137 * * * \\
(2.90)\end{array}$ & $\begin{array}{c}0.165 * * * \\
(3.23)\end{array}$ & $\begin{array}{c}0.202 * * \\
(2.20)\end{array}$ & $\begin{array}{c}0.146^{* *} \\
(2.34)\end{array}$ & $\begin{array}{c}0.404^{*} \\
(1.82)\end{array}$ & $\begin{array}{l}0.038 \\
(0.34)\end{array}$ \\
\hline $1^{\text {st }}$ revenue quartile & & $\begin{array}{c}0.514 * * * \\
\quad(9.52)\end{array}$ & $\begin{array}{c}0.492 * * * \\
\quad(8.19)\end{array}$ & $\begin{array}{c}0.528^{* * *} * \\
\quad(6.21)\end{array}$ & $\begin{array}{c}0.673 * * * \\
\quad(5.29)\end{array}$ & $\begin{array}{c}0.265^{* * *} * \\
\quad(8.21)\end{array}$ \\
\hline $2^{\text {nd }}$ revenue quartile & & $\begin{array}{c}0.272 * * * \\
(7.31)\end{array}$ & $\begin{array}{c}0.269 * * * \\
(7.26)\end{array}$ & $\begin{array}{c}0.274 * * * \\
(4.51)\end{array}$ & $\begin{array}{c}0.390 * * * \\
(7.53)\end{array}$ & $\begin{array}{c}0.167 * * * \\
(6.30)\end{array}$ \\
\hline $3^{\text {rd }}$ revenue quartile & & $\begin{array}{c}0.095 * * * \\
(3.57)\end{array}$ & $\begin{array}{c}0.085 * * \\
(2.52)\end{array}$ & $\begin{array}{c}0.102 * * * \\
(2.64)\end{array}$ & $\begin{array}{c}0.202^{* * *} \\
(3.24)\end{array}$ & $\begin{array}{c}0.086^{* * *} \\
(3.48)\end{array}$ \\
\hline $4^{\text {th }}$ revenue quartile & & $\begin{array}{l}-0.017 \\
(-0.72)\end{array}$ & $\begin{array}{l}-0.027 \\
(-1.00)\end{array}$ & $\begin{array}{l}-0.010 \\
(-0.26)\end{array}$ & $\begin{array}{c}0.009 \\
(0.17)\end{array}$ & $\begin{array}{c}0.036^{* *} \\
(2.06)\end{array}$ \\
\hline Constant & $\begin{array}{c}0.559 * * * \\
(17.43)\end{array}$ & $\begin{array}{c}0.578 * * * \\
(15.91)\end{array}$ & $\begin{array}{c}0.572 * * * \\
(15.80)\end{array}$ & $\begin{array}{c}0.593 * * * \\
(11.83)\end{array}$ & $\begin{array}{c}0.696 * * * \\
(13.82)\end{array}$ & $\begin{array}{c}0.290 * * * \\
(10.03)\end{array}$ \\
\hline Observations & 52.199 & 52.199 & 22.802 & 29.397 & 11.256 & 11.334 \\
\hline R-squared & 0.069 & 0.086 & 0.090 & 0.084 & 0.170 & 0.134 \\
\hline
\end{tabular}




\section{Table 7: Determinants of allocation: bank-by-bank regressions}

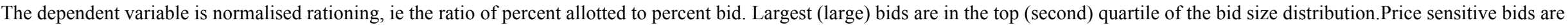

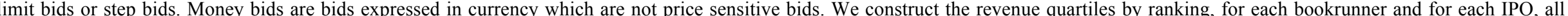

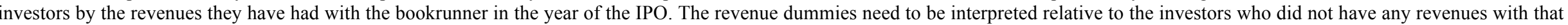

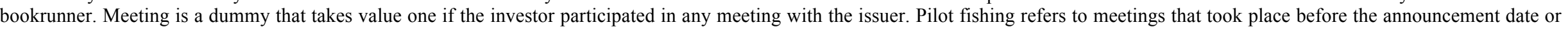

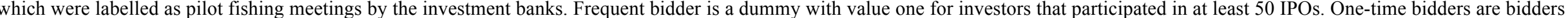

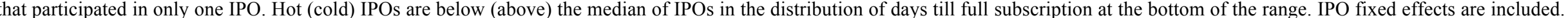

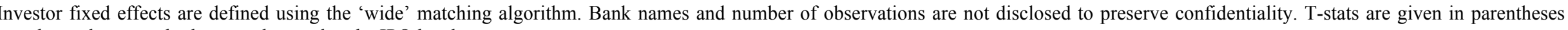
based on robust standard errors clustered at the IPO level.

\begin{tabular}{|c|c|c|c|c|c|c|c|c|c|c|}
\hline \multirow[b]{2}{*}{ Explanatory variables } & \multicolumn{10}{|c|}{ Dependent variable: normalised rationing } \\
\hline & Bank 1 & Bank 2 & Bank 3 & Bank 4 & Bank 5 & Bank 6 & Bank 7 & Bank 8 & Bank 9 & others \\
\hline Largest & $\begin{array}{c}0.185 * * \\
(2.20)\end{array}$ & $\begin{array}{c}0.205 * * * \\
(4.00)\end{array}$ & $\begin{array}{c}0.0268 \\
(0.36)\end{array}$ & $\begin{array}{c}0.123^{*} \\
(1.99)\end{array}$ & $\begin{array}{c}0.218^{* * *} \\
(4.56)\end{array}$ & $\begin{array}{c}0.197 * * * \\
(2.98)\end{array}$ & $\begin{array}{c}0.371 * * * \\
(4.45)\end{array}$ & $\begin{array}{c}0.287 * \\
(2.09)\end{array}$ & $\begin{array}{c}0.522 * * * \\
(3.41)\end{array}$ & $\begin{array}{c}0.177 * * * \\
(3.34)\end{array}$ \\
\hline Large & $\begin{array}{c}0.125^{* *} \\
(2.15)\end{array}$ & $\begin{array}{c}0.131 * * * \\
(3.20)\end{array}$ & $\begin{array}{c}0.044 \\
(0.80)\end{array}$ & $\begin{array}{c}0.132 * * \\
(2.31)\end{array}$ & $\begin{array}{c}0.192 * * \\
(2.32)\end{array}$ & $\begin{array}{c}0.077 * * \\
(2.13)\end{array}$ & $\begin{array}{l}0.048 \\
(0.78)\end{array}$ & $\begin{array}{c}0.138^{* * *} \\
(4.81)\end{array}$ & $\begin{array}{c}0.222^{* * *} \\
(3.53)\end{array}$ & $\begin{array}{c}0.074 * \\
(1.74)\end{array}$ \\
\hline Price sensitive bid & $\begin{array}{l}0.011 \\
(0.19)\end{array}$ & $\begin{array}{c}0.088 * * * \\
(2.94)\end{array}$ & $\begin{array}{c}0.100 * * \\
(2.23)\end{array}$ & $\begin{array}{l}-0.038 \\
(-0.44)\end{array}$ & $\begin{array}{c}0.154 * * * \\
(6.22)\end{array}$ & $\begin{array}{l}-0.142 \\
(-0.95)\end{array}$ & $\begin{array}{c}0.459 * * \\
(2.25)\end{array}$ & $\begin{array}{l}0.092 \\
(1.07)\end{array}$ & $\begin{array}{l}0.018 \\
(0.26)\end{array}$ & $\begin{array}{c}0.081^{* * *} \\
(3.28)\end{array}$ \\
\hline Money bid & $\begin{array}{c}-0.131 * * \\
(-2.22)\end{array}$ & $\begin{array}{l}-0.003 \\
(-0.11)\end{array}$ & $\begin{array}{l}0.005 \\
(0.11)\end{array}$ & $\begin{array}{l}-0.162 \\
(-1.51)\end{array}$ & $\begin{array}{c}0.174 * * \\
(2.26)\end{array}$ & $\begin{array}{c}-0.411 * * \\
(-2.29)\end{array}$ & $\begin{array}{c}0.211^{* *} \\
(2.43)\end{array}$ & $\begin{array}{c}-0.068^{*} \\
(-2.22)\end{array}$ & $\begin{array}{l}-0.029 \\
(-0.79)\end{array}$ & $\begin{array}{l}0.011 \\
(0.33)\end{array}$ \\
\hline Early & $\begin{array}{c}-0.075^{* *} \\
(-2.63)\end{array}$ & $\begin{array}{l}-0.008 \\
(-0.35)\end{array}$ & $\begin{array}{c}-0.099 * * * \\
(-2.90)\end{array}$ & $\begin{array}{l}0.179 \\
(1.41)\end{array}$ & $\begin{array}{c}-0.077 * * \\
(-2.28)\end{array}$ & $\begin{array}{l}0.150 \\
(0.71)\end{array}$ & $\begin{array}{l}0.052 \\
(1.08)\end{array}$ & $\begin{array}{c}-0.154^{*} \\
(-2.04)\end{array}$ & $\begin{array}{l}-0.006 \\
(-0.081)\end{array}$ & $\begin{array}{l}-0.032 \\
(-0.92)\end{array}$ \\
\hline Revised bid & $\begin{array}{l}0.040 \\
(0.95)\end{array}$ & $\begin{array}{c}0.028 \\
(1.23)\end{array}$ & $\begin{array}{l}0.037 \\
(0.63)\end{array}$ & $\begin{array}{l}-0.034 \\
(-0.69)\end{array}$ & $\begin{array}{l}-0.046 \\
(-0.45)\end{array}$ & $\begin{array}{l}-0.018 \\
(-0.30)\end{array}$ & $\begin{array}{l}0.044 \\
(0.67)\end{array}$ & $\begin{array}{l}-0.007 \\
(-0.19)\end{array}$ & & \\
\hline Meeting & $\begin{array}{c}0.297 * * * \\
(3.96)\end{array}$ & $\begin{array}{c}0.157 * * * \\
(4.18)\end{array}$ & $\begin{array}{c}0.173 * * * \\
(4.84)\end{array}$ & $\begin{array}{c}0.431 * * * \\
(8.54)\end{array}$ & $\begin{array}{l}-0.043 \\
(-0.57)\end{array}$ & $\begin{array}{c}0.211 * * * \\
(3.82)\end{array}$ & & $\begin{array}{l}0.380 \\
(1.63)\end{array}$ & $\begin{array}{c}0.492 * * * \\
(4.88)\end{array}$ & $\begin{array}{c}0.338 * * * \\
(3.29)\end{array}$ \\
\hline Pilot fishing & $\begin{array}{c}0.426 * * * \\
(3.35)\end{array}$ & $\begin{array}{c}0.206 * * * \\
(3.75)\end{array}$ & $\begin{array}{c}0.221^{*} \\
(1.87)\end{array}$ & $\begin{array}{c}0.152^{*} \\
(1.85)\end{array}$ & $\begin{array}{l}0.635^{*} \\
(1.99)\end{array}$ & $\begin{array}{l}-0.336 \\
(-0.84)\end{array}$ & & $\begin{array}{c}0.653 * * * \\
(4.09)\end{array}$ & $\begin{array}{l}-0.090 \\
(-0.63)\end{array}$ & $\begin{array}{l}0.133 \\
(0.90)\end{array}$ \\
\hline Frequent bidder & $\begin{array}{c}0.055^{* *} \\
(2.06)\end{array}$ & $\begin{array}{c}0.091^{*} \\
(1.94)\end{array}$ & $\begin{array}{l}-0.005 \\
(-0.12)\end{array}$ & $\begin{array}{l}-0.059 \\
(-0.69)\end{array}$ & $\begin{array}{l}0.005 \\
(0.13)\end{array}$ & $\begin{array}{l}-0.012 \\
(-0.19)\end{array}$ & $\begin{array}{c}0.152 * * * \\
(3.35)\end{array}$ & $\begin{array}{c}0.230 * * * \\
(5.35)\end{array}$ & $\begin{array}{c}-0.085 * * * \\
(-3.74)\end{array}$ & $\begin{array}{c}0.085 * * \\
(2.64)\end{array}$ \\
\hline One-time bidder & $\begin{array}{c}0.287 * * \\
(2.59)\end{array}$ & $\begin{array}{c}0.240 * * * \\
(3.59)\end{array}$ & $\begin{array}{c}0.356^{* * *} \\
(3.22)\end{array}$ & $\begin{array}{l}-0.071 \\
(-1.33)\end{array}$ & $\begin{array}{l}0.172 \\
(1.64)\end{array}$ & $\begin{array}{c}-0.232 * * \\
(-2.49)\end{array}$ & $\begin{array}{l}0.062 \\
(1.59)\end{array}$ & $\begin{array}{l}-0.024 \\
(-0.64)\end{array}$ & $\begin{array}{l}0.299 \\
(1.21)\end{array}$ & $\begin{array}{c}0.106^{* *} \\
(2.21)\end{array}$ \\
\hline $1^{\text {st }}$ revenue quartile & $\begin{array}{c}0.626^{* * *} \\
(7.41)\end{array}$ & $\begin{array}{c}0.578 * * * \\
(10.38)\end{array}$ & $\begin{array}{c}0.717 * * * \\
(5.87)\end{array}$ & $\begin{array}{l}0.449^{*} \\
(1.82)\end{array}$ & $\begin{array}{c}0.637 * * \\
(2.68)\end{array}$ & $\begin{array}{l}-0.017 \\
(-0.11)\end{array}$ & $\begin{array}{c}0.573 * * \\
(2.67)\end{array}$ & $\begin{array}{c}0.250 * * * \\
(3.79)\end{array}$ & $\begin{array}{c}0.563 * * * \\
(9.17)\end{array}$ & $\begin{array}{c}0.308 * * * \\
(2.81)\end{array}$ \\
\hline $2^{\text {nd }}$ revenue quartile & $\begin{array}{c}0.380^{* * *} \\
(5.16)\end{array}$ & $\begin{array}{c}0.249 * * * \\
(6.57)\end{array}$ & $\begin{array}{c}0.670 * * * \\
(3.45)\end{array}$ & $\begin{array}{c}0.094^{*} \\
(1.73)\end{array}$ & $\begin{array}{c}0.134 * * * \\
(2.92)\end{array}$ & $\begin{array}{l}-0.186 \\
(-0.89)\end{array}$ & $\begin{array}{c}0.294^{*} \\
(1.95)\end{array}$ & $\begin{array}{c}0.222 * * \\
(2.36)\end{array}$ & $\begin{array}{l}0.123 \\
(1.19)\end{array}$ & $\begin{array}{c}0.258 * * * \\
(3.05)\end{array}$ \\
\hline $3^{\text {rd }}$ revenue quartile & $\begin{array}{c}0.165 * * * \\
(3.36)\end{array}$ & $\begin{array}{c}0.160 * * * \\
(5.01)\end{array}$ & $\begin{array}{c}0.344 * * * \\
\quad(5.62)\end{array}$ & $\begin{array}{l}-0.038 \\
(-0.75)\end{array}$ & $\begin{array}{l}0.016 \\
(0.18)\end{array}$ & $\begin{array}{c}-0.442 * * \\
(-2.48)\end{array}$ & $\begin{array}{c}-0.203^{*} \\
(-1.92)\end{array}$ & $\begin{array}{l}0.102 \\
(1.14)\end{array}$ & $\begin{array}{l}0.005 \\
(0.05)\end{array}$ & $\begin{array}{l}0.081 \\
(1.55)\end{array}$ \\
\hline $4^{\text {th }}$ revenue quartile & $\begin{array}{l}-0.029 \\
(-0.81)\end{array}$ & $\begin{array}{l}-0.026 \\
(-0.58)\end{array}$ & $\begin{array}{c}0.511^{* * *} \\
(5.49)\end{array}$ & $\begin{array}{c}-0.123 * * * \\
(-4.63)\end{array}$ & $\begin{array}{c}-0.144 * * * \\
(-5.40)\end{array}$ & $\begin{array}{c}-0.501 * * \\
(-2.44)\end{array}$ & $\begin{array}{c}-0.427 * * * \\
(-5.08)\end{array}$ & $\begin{array}{l}0.015 \\
(0.20)\end{array}$ & $\begin{array}{l}-0.099 \\
(-1.44)\end{array}$ & $\begin{array}{l}0.012 \\
(0.29)\end{array}$ \\
\hline Constant & $\begin{array}{c}0.433 * * * \\
\quad(8.38)\end{array}$ & $\begin{array}{c}0.365^{* * *} * \\
(14.22)\end{array}$ & $\begin{array}{c}0.445^{* * *} * \\
(11.28)\end{array}$ & $\begin{array}{c}0.601 * * * \\
\quad(9.06)\end{array}$ & $\begin{array}{c}0.438^{* * *} * \\
\quad(5.72)\end{array}$ & $\begin{array}{c}1.149 * * * \\
(4.05)\end{array}$ & $\begin{array}{c}0.281 * * * \\
(5.24)\end{array}$ & $\begin{array}{c}0.587 * * * \\
(15.05)\end{array}$ & $\begin{array}{c}0.302 * * * \\
\quad(6.67)\end{array}$ & $\begin{array}{c}0.586^{* * *} \\
(18.17)\end{array}$ \\
\hline Observations & XXX & XXX & XXX & XXX & XXX & XXX & XXX & XXX & XXX & XXX \\
\hline R-squared & 0.086 & 0.097 & 0.090 & 0.172 & 0.082 & 0.096 & 0.156 & 0.116 & 0.116 & 0.134 \\
\hline
\end{tabular}




\section{Table 8: Determinants of allocation, investor and bank-investor fixed effects}

The dependent variable is normalised rationing, ie the ratio of percent allotted to percent bid. Largest (large) bids are in the top (second) quartile of the bid size distribution. Price sensitive bids are limit bids or step bids. Money bids are bids expressed in currency which are not price sensitive bids. We construct the revenue quartiles by ranking, for each bookrunner and for each IPO, all investors by the revenues they have had with the bookrunner in the year of the IPO. The revenue dummies need to be interpreted relative to the investors who did not have any revenues with that bookrunner. Meeting is a dummy that takes value one if investor participated in any meeting with the issuer. Pilot fishing refers to meetings that took place before the announcement date or which were labelled as pilot fishing meetings by the investment banks. One-time bidders are bidders that participated in only one IPO. IPO and Bank fixed effects are included. Investor fixed effects and investor-bank fixed effects are defined using the 'wide' matching algorithm. T-stats are given in parentheses based on robust standard errors clustered at the IPO level.

\begin{tabular}{|c|c|c|}
\hline Explanatory variables & $\begin{array}{c}\text { Investor fixed } \\
\text { effects } \\
(1)\end{array}$ & $\begin{array}{l}\text { Investor-bank } \\
\text { fixed effects } \\
\text { (2) }\end{array}$ \\
\hline Largest & $\begin{array}{c}-0.138^{* * *} \\
(-2.67)\end{array}$ & $\begin{array}{c}-0.174^{* *} \\
(-2.60)\end{array}$ \\
\hline Large & $\begin{array}{l}-0.053 \\
(-1.52)\end{array}$ & $\begin{array}{c}-0.072^{*} \\
(-1.67)\end{array}$ \\
\hline Price sensitive bid & $\begin{array}{l}0.053^{*} \\
(1.84)\end{array}$ & $\begin{array}{l}0.052 \\
(1.37)\end{array}$ \\
\hline Money bid & $\begin{array}{l}-0.022 \\
(-0.68)\end{array}$ & $\begin{array}{l}-0.031 \\
(-0.72)\end{array}$ \\
\hline Early & $\begin{array}{c}0.069 * * * \\
(3.49)\end{array}$ & $\begin{array}{c}0.067 * * * \\
(2.64)\end{array}$ \\
\hline Revised bid & $\begin{array}{l}0.012 \\
(0.42)\end{array}$ & $\begin{array}{l}0.009 \\
(0.25)\end{array}$ \\
\hline Meeting & $\begin{array}{c}0.106 * * * \\
(5.77)\end{array}$ & $\begin{array}{c}0.142^{* * *} \\
(5.64)\end{array}$ \\
\hline Pilot fishing & $\begin{array}{c}0.093 * * * \\
(2.76)\end{array}$ & $\begin{array}{c}0.090^{* *} \\
(2.19)\end{array}$ \\
\hline $1^{\text {st }}$ revenue quartile & $\begin{array}{c}0.133 * * * \\
(5.09)\end{array}$ & $\begin{array}{c}0.179 * * * \\
(3.24)\end{array}$ \\
\hline $2^{\text {nd }}$ revenue quartile & $\begin{array}{c}0.068 * * * \\
(2.96)\end{array}$ & $\begin{array}{c}0.095 * * \\
(2.10)\end{array}$ \\
\hline $3^{\text {rd }}$ revenue quartile & $\begin{array}{l}0.024 \\
(1.41)\end{array}$ & $\begin{array}{l}0.033 \\
(0.76)\end{array}$ \\
\hline $4^{\text {th }}$ revenue quartile & $\begin{array}{c}0.035^{*} \\
(1.86)\end{array}$ & $\begin{array}{l}0.038 \\
(0.66)\end{array}$ \\
\hline Constant & $\begin{array}{c}1.079 * * * \\
(22.13)\end{array}$ & $\begin{array}{c}0.961 * * * \\
(16.04)\end{array}$ \\
\hline Observations & 52,199 & 52,199 \\
\hline R-squared & 0.498 & 0.612 \\
\hline Investor fixed effects & Yes & Yes \\
\hline Investor-bank fixed effects & No & Yes \\
\hline
\end{tabular}




\section{Table 9: Allocation in hot vs cold IPOs}

The dependent variable is normalised rationing, i.e. the ratio of percent allotted to percent bid. Largest (large) bids are in the top (second) quartile of the bid size distribution. Price sensitive bids are limit bids or step bids. Money bids are bids expressed in currency which are not price sensitive bids. We construct the revenue quartiles by ranking, for each bookrunner and for each IPO, all investors by the revenues they have had with the bookrunner in the year of the IPO. The revenue dummies need to be interpreted relative to the investors who did not have any revenues with that bookrunner. Meeting is a dummy that takes value one if investor participated in any meeting with the issuer. Pilot fishing refers to meetings that took place before the announcement date or which were labelled as pilot fishing meetings by the investment banks. One-time bidders are bidders that participated in only one IPO. Hot (cold) IPOs are below (above) the median of the time till full subscription at the lower end of the initial price range. For a few IPOs, the initial price range was not reported to us, and so we exclude these from this part of the analysis. IPO and Bank fixed effects are included. Investor fixed effects and investor-bank fixed effects are defined using the 'wide' matching algorithm. T-stats are given in parentheses based on robust standard errors clustered at the IPO level.

\begin{tabular}{|c|c|c|c|c|}
\hline Explanatory variables & $\begin{array}{c}\text { Hot } \\
\text { IPOs } \\
(1)\end{array}$ & $\begin{array}{c}\text { Cold } \\
\text { IPOs } \\
(2)\end{array}$ & $\begin{array}{c}\text { Hot } \\
\text { IPOs } \\
(3)\end{array}$ & $\begin{array}{c}\text { Cold } \\
\text { IPOs } \\
(4)\end{array}$ \\
\hline Largest & $\begin{array}{c}0.161 * * * \\
(3.27)\end{array}$ & $\begin{array}{c}0.229 * * \\
(6.68)\end{array}$ & $\begin{array}{c}-0.212 * * \\
(-2.551)\end{array}$ & $\begin{array}{l}-0.0262 \\
(-0.639)\end{array}$ \\
\hline Large & $\begin{array}{c}0.103 * * \\
(2.49)\end{array}$ & $\begin{array}{c}0.161 * * * \\
(6.87)\end{array}$ & $\begin{array}{c}-0.0940^{*} \\
(-1.763)\end{array}$ & $\begin{array}{l}0.0280 \\
(1.406)\end{array}$ \\
\hline Price sensitive bid & $\begin{array}{c}0.070^{*} \\
(1.73)\end{array}$ & $\begin{array}{l}0.021 \\
(1.03)\end{array}$ & $\begin{array}{c}0.0714 * \\
(1.668)\end{array}$ & $\begin{array}{l}0.0189 \\
(0.583)\end{array}$ \\
\hline Money bid & $\begin{array}{l}-0.058 \\
(-1.08)\end{array}$ & $\begin{array}{c}-0.085^{* * *} \\
(-4.27)\end{array}$ & $\begin{array}{l}-0.00440 \\
(-0.0859)\end{array}$ & $\begin{array}{l}-0.0536 \\
(-1.510)\end{array}$ \\
\hline Early & $\begin{array}{l}-0.022 \\
(-0.39)\end{array}$ & $\begin{array}{c}-0.035^{* *} \\
(-2.14)\end{array}$ & $\begin{array}{c}0.0867 * * * \\
(2.815)\end{array}$ & $\begin{array}{c}0.0459 * * * \\
(2.863)\end{array}$ \\
\hline Revised bid & $\begin{array}{l}-0.015 \\
(-0.36)\end{array}$ & $\begin{array}{c}0.043 * * * \\
(2.74)\end{array}$ & $\begin{array}{l}-0.0136 \\
(-0.292)\end{array}$ & $\begin{array}{c}0.00672 \\
(0.419)\end{array}$ \\
\hline Meeting & $\begin{array}{c}0.278 * * * \\
(10.14)\end{array}$ & $\begin{array}{c}0.138 * * * \\
(4.93)\end{array}$ & $\begin{array}{c}0.117 * * * \\
(4.935)\end{array}$ & $\begin{array}{l}0.0326 \\
(1.531)\end{array}$ \\
\hline Pilot fishing & $\begin{array}{c}0.278 * * * \\
(3.96)\end{array}$ & $\begin{array}{c}0.139 * * \\
(2.50)\end{array}$ & $\begin{array}{c}0.0812 * \\
(1.907)\end{array}$ & $\begin{array}{l}0.0451 \\
(1.119)\end{array}$ \\
\hline One time bidder & $\begin{array}{c}0.103 * * * \\
(2.75)\end{array}$ & $\begin{array}{c}0.042 * * \\
(2.12)\end{array}$ & & \\
\hline Frequent bidder & $\begin{array}{c}0.219 * * * \\
(2.72)\end{array}$ & $\begin{array}{c}0.085^{* *} \\
(2.13)\end{array}$ & & \\
\hline $1^{\text {st }}$ revenue quartile & $\begin{array}{c}0.653 * * * \\
(8.44)\end{array}$ & $\begin{array}{c}0.278 * * * \\
(7.13)\end{array}$ & $\begin{array}{c}0.147 * * * \\
(4.598)\end{array}$ & $\begin{array}{l}0.0351 \\
(1.600)\end{array}$ \\
\hline $2^{\text {nd }}$ revenue quartile & $\begin{array}{c}0.333 * * * \\
(6.32)\end{array}$ & $\begin{array}{c}0.168 * * * \\
(4.36)\end{array}$ & $\begin{array}{c}0.090 * * * \\
(2.863)\end{array}$ & $\begin{array}{l}0.0136 \\
(0.698)\end{array}$ \\
\hline $3^{\text {rd }}$ revenue quartile & $\begin{array}{c}0.127 * * * \\
(3.59)\end{array}$ & $\begin{array}{c}0.048 * \\
(1.67)\end{array}$ & $\begin{array}{c}0.051 * * \\
(2.501)\end{array}$ & $\begin{array}{l}-0.0228 \\
(-0.956)\end{array}$ \\
\hline $4^{\text {th }}$ revenue quartile & $\begin{array}{l}-0.018 \\
(-0.55)\end{array}$ & $\begin{array}{l}-0.009 \\
(-0.32)\end{array}$ & $\begin{array}{l}0.0392 \\
(1.556)\end{array}$ & $\begin{array}{l}0.0137 \\
(0.612)\end{array}$ \\
\hline Constant & $\begin{array}{c}0.572 * * * \\
(10.49)\end{array}$ & $\begin{array}{c}0.640 * * * \\
(30.56)\end{array}$ & $\begin{array}{c}0.707 * * * \\
(16.25)\end{array}$ & $\begin{array}{c}1.050 * * * \\
(18.60)\end{array}$ \\
\hline Observations & 32,294 & 16,487 & 32,294 & 16,487 \\
\hline R-squared & 0.082 & 0.136 & 0.537 & 0.579 \\
\hline Investor fixed effects & No & No & Yes & Yes \\
\hline Investor-bank fixed effects & No & No & No & No \\
\hline
\end{tabular}




\section{Table 10: Expected profitability of bids}

The dependent variable is expected profitablity of bids. Expected first trading day price increases are determined from a model (included in the internet appendix MORE Largest (large) bids are in the top (second) quartile of the bid size distribution. Price sensitive bids are limit bids or step bids. Money bids are bids expressed in currency which are not price sensitive bids. We construct the revenue quartiles by ranking, for each bookrunner and for each IPO, all investors by the revenues they have had with the bookrunner in the year of the IPO, in the year before the IPO or in the year after the IPO. The revenue dummies need to be interpreted relative to the investors who did not have any revenues with that bookrunner. Meeting is a dummy that takes value one if investor participated in any meeting with the issuer. Pilot fishing refers to meetings that took place before the announcement date or which were labelled as pilot fishing meetings by the investment banks. One-time bidders are bidders that participated in only one IPO. IPO and Bank fixed effects are included. Investor fixed effects and investor-bank fixed effects are defined using the 'wide' matching algorithm. T-stats are given in parentheses based on robust standard errors clustered at the IPO level.

\begin{tabular}{|c|c|c|c|c|}
\hline $\begin{array}{l}\text { Explanatory } \\
\text { variables }\end{array}$ & $\begin{array}{c}\text { Baseline } \\
\text { (1) }\end{array}$ & $\begin{array}{l}\text { Including investor } \\
\text { revenues } \\
\text { (2) }\end{array}$ & $\begin{array}{l}\text { Investor fixed } \\
\text { effects } \\
\text { (3) }\end{array}$ & $\begin{array}{c}\text { Investor-bank } \\
\text { fixed effects } \\
\text { (4) }\end{array}$ \\
\hline Largest & $\begin{array}{c}0.227 * * * \\
(3.523)\end{array}$ & $\begin{array}{c}0.163 * * \\
(2.404)\end{array}$ & $\begin{array}{l}-0.0773 \\
(-0.736)\end{array}$ & $\begin{array}{c}0.229 * * * \\
(6.68)\end{array}$ \\
\hline Large & $\begin{array}{c}0.125 * * \\
(2.598)\end{array}$ & $\begin{array}{c}0.103 * * \\
(2.056)\end{array}$ & $\begin{array}{l}-0.0541 \\
(-0.863)\end{array}$ & $\begin{array}{c}-0.103 \\
(-0.870)\end{array}$ \\
\hline Price sensitive bid & $\begin{array}{c}0.255^{* *} \\
(2.078)\end{array}$ & $\begin{array}{c}0.258 * * \\
(2.103)\end{array}$ & $\begin{array}{c}0.115 \\
(1.050)\end{array}$ & $\begin{array}{l}-0.0583 \\
(-0.772)\end{array}$ \\
\hline Money bid & $\begin{array}{l}0.0673 \\
(0.933)\end{array}$ & $\begin{array}{l}0.0707 \\
(0.992)\end{array}$ & $\begin{array}{l}-0.0173 \\
(-0.301)\end{array}$ & $\begin{array}{c}0.117 \\
(0.982)\end{array}$ \\
\hline Early & $\begin{array}{l}-0.0255 \\
(-0.700)\end{array}$ & $\begin{array}{l}-0.0147 \\
(-0.411)\end{array}$ & $\begin{array}{c}0.0915 * * * \\
(2.790)\end{array}$ & $\begin{array}{l}-0.0377 \\
(-0.587)\end{array}$ \\
\hline Revised bid & $\begin{array}{l}0.0174 \\
(0.300)\end{array}$ & $\begin{array}{c}0.00747 \\
(0.128)\end{array}$ & $\begin{array}{c}0.00950 \\
(0.163)\end{array}$ & $\begin{array}{c}0.0733^{*} \\
(1.859)\end{array}$ \\
\hline Meeting & $\begin{array}{c}0.110 \\
(1.016)\end{array}$ & $\begin{array}{l}0.0821 \\
(0.758)\end{array}$ & $\begin{array}{l}-0.0514 \\
(-0.473)\end{array}$ & $\begin{array}{l}0.0169 \\
(0.255)\end{array}$ \\
\hline Pilot fishing & $\begin{array}{c}0.0560 \\
(0.256)\end{array}$ & $\begin{array}{c}0.0365 \\
(0.165)\end{array}$ & $\begin{array}{l}-0.0779 \\
(-0.339)\end{array}$ & $\begin{array}{l}-0.0825 \\
(-0.571)\end{array}$ \\
\hline Frequent bidder & $\begin{array}{c}0.160 * * * \\
(3.057)\end{array}$ & $\begin{array}{c}0.00624 \\
(0.131)\end{array}$ & & \\
\hline One-time bidder & $\begin{array}{c}-0.0206 \\
(-0.0914)\end{array}$ & $\begin{array}{l}0.0406 \\
(0.186)\end{array}$ & & \\
\hline $1^{\text {st }}$ revenue quartile & & $\begin{array}{c}0.491 * * * \\
(4.564)\end{array}$ & $\begin{array}{c}0.265^{* *} \\
(2.304)\end{array}$ & $\begin{array}{c}0.141 \\
(0.431)\end{array}$ \\
\hline $2^{\text {nd }}$ revenue quartile & & $\begin{array}{c}0.340 * * * \\
(3.429)\end{array}$ & $\begin{array}{l}0.196 * * \\
(2.092)\end{array}$ & $\begin{array}{l}0.0713 \\
(0.285)\end{array}$ \\
\hline $3^{\text {rd }}$ revenue quartile & & $\begin{array}{l}0.170^{* *} \\
(2.142)\end{array}$ & $\begin{array}{l}0.126^{*} \\
(1.726)\end{array}$ & $\begin{array}{l}0.0869 \\
(0.440)\end{array}$ \\
\hline $4^{\text {th }}$ revenue quartile & & $\begin{array}{c}0.0595 \\
(0.848)\end{array}$ & $\begin{array}{l}0.0799 \\
(1.453)\end{array}$ & $\begin{array}{c}0.0395 \\
(0.267)\end{array}$ \\
\hline Constant & $\begin{array}{c}0.390 * * * \\
(5.753)\end{array}$ & $\begin{array}{c}0.324 * * * \\
(4.679)\end{array}$ & $\begin{array}{c}0.574 * * * \\
(6.278)\end{array}$ & $\begin{array}{c}0.636^{* * *} \\
(4.139)\end{array}$ \\
\hline Observations & 52,199 & 52,199 & 52,199 & 52,199 \\
\hline R-squared & 0.012 & 0.018 & 0.364 & 0.549 \\
\hline Investor fixed effects & No & No & Yes & No \\
\hline Investor-bank fixed effects & No & No & No & Yes \\
\hline
\end{tabular}

